\title{
EDUCAÇÃO
}

\section{POLÍTICAS SOCIAIS: acompanhamento e análise}

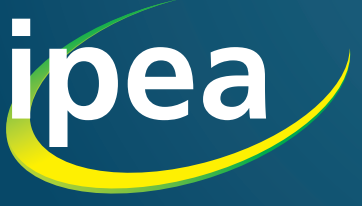




\section{Governo Federal}

Ministério do Planejamento, Desenvolvimento e Gestão

Ministro Dyogo Henrique de Oliveira

\section{ipea mistatud de peautis Econômica Aplicada}

Fundação pública vinculada ao Ministério do Planejamento, Desenvolvimento e Gestão, o Ipea fornece suporte técnico e institucional às ações governamentais - possibilitando a formulação de inúmeras políticas públicas e programas de desenvolvimento brasileiros - e disponibiliza, para a sociedade, pesquisas e estudos realizados por seus técnicos.

\section{POLÍTICAS SOCIAIS} acompanhamento e análise

Diretoria de Estudos e Políticas Sociais

Conselho Editorial

Alexandre Arbex Valadares

Ana Cleusa Serra Mesquita

Antonio Teixeira Lima Junior

Edvaldo Batista de Sá

José Aparecido Carlos Ribeiro

Marcelo Galiza Pereira de Souza

Natália de Oliveira Fontoura

Roberto Henrique Sieczkowski Gonzalez

Colaboradores

\begin{tabular}{l|l} 
Educação & $\begin{array}{l}\text { Milko Matijascic } \\
\text { Paulo Roberto Corbucci }\end{array}$
\end{tabular}

\section{Presidente}

Ernesto Lozardo

Diretor de Desenvolvimento Institucional

Rogério Boueri Miranda

Diretor de Estudos e Políticas do Estado, das Instituições e da Democracia

Alexandre de Ávila Gomide

\section{Diretor de Estudos e Políticas}

Macroeconômicas

José Ronaldo de Castro Souza Júnior

Diretor de Estudos e Políticas Regionais, Urbanas e Ambientais

Alexandre Xavier Ywata de Carvalho

Diretor de Estudos e Políticas Setoriais de Inovação e Infraestrutura

Fabiano Mezadre Pompermayer

\section{Diretora de Estudos e Políticas Sociais}

Lenita Maria Turchi

\section{Diretor de Estudos e Relações Econômicas} e Políticas Internacionais

Ivan Tiago Machado Oliveira

Assessora-chefe de Imprensa e Comunicação

Regina Alvarez

Ouvidoria: http://www.ipea.gov.br/ouvidoria

URL: http://www.ipea.gov.br 


\section{EDUCAÇÃO}

\section{APRESENTAÇÃO}

O objetivo geral deste capítulo é o de acompanhar a execução do Plano Nacional de Educação (PNE) em 2015, tendo em vista que sua aprovação ocorreu em meados de 2014, momento em que estava em curso a execução do orçamento autorizado no ano anterior. Portanto, não houve possibilidades de grandes alteraçóes no volume de recursos que seria aportado à área educacional.

Cabe lembrar que o PNE 2014-2024 contempla metas bastante ousadas, a começar pela última delas, que trata do financiamento das demais, a qual fixou em $10 \%$ do produto interno bruto (PIB) os investimentos em educação ao final desse decênio, tendo ainda como meta intermediária, para o quinto ano de sua vigência, a proporção de $7 \%$ do PIB.

De acordo com estimativas preliminares do Instituto Nacional de Estudos e Pesquisas Educacionais Anísio Teixeira (Inep), do Ministério da Educação (MEC), os investimentos públicos em educaçáo, que haviam atingido 6,0\% do PIB em 2013, ficaram praticamente estagnados em 2014, com acréscimo de apenas 0,04\% em relação ao ano anterior. Sendo confirmado este percentual, o montante de recursos públicos investidos em educação teria sido da ordem de $\mathrm{R} \$ 349$ bilhões. Somente por intermédio do Fundo de Manutenção e Desenvolvimento da Educação Básica e de Valorização dos Profissionais da Educação (Fundeb), houve aporte de R $\$ 126,2$ bilhóes (2,2\% do PIB). Por sua vez, os gastos realizados pelo MEC totalizaram R $\$ 71,1$ bilhóes (1,2\% do PIB), excluídos deste montante os dispêndios com aposentados e pensionistas e a complementação da União ao Fundeb. Por fim, o Fundo de Financiamento Estudantil (Fies) respondeu por R \$ 12,3 bilhóes (0,2\% do PIB) que, somados aos dispêndios anteriores, corresponderam a 3,6\% do PIB em 2014.

Apesar de ainda não ter sido divulgada pelo Inep a proporçáo do PIB investida pelas três instâncias de governo na educação em 2015, ao utilizar-se como proxy deste indicador os dispêndios realizados por intermédio do Fundeb, MEC e Fies, chega-se à proporção de $3,5 \%$ no ano em questão. Portanto, considerando-se que a evolução do PIB no biênio 2015-2016 foi praticamente idêntica (-3,8\% e $-3,6 \%)$ e que a estimativa dos investimentos públicos em educação como proporção 
do PIB não aponta para crescimento em 2015, torna-se ainda mais improvável o cumprimento da meta 20 , seja em relação aos $7 \%$ (meta intermediária), ou no que concerne aos $10 \%$ em 2024.

Tendo em vista que a meta 20 assume a condição de meta meio para o alcance das demais, não são favoráveis as perspectivas de cumprimento das outras dezenove metas, sobretudo daquelas que visam à ampliaçáo da oferta, uma vez que pressupóem aumento de investimentos em infraestrutura e na manutenção dos serviços.

Para além do acompanhamento dos indicadores que integram as metas do PNE 2014-2024, terão ênfase na análise alguns temas considerados centrais. $\mathrm{Na}$ educaçáo básica, optou-se por tratar da questão da qualidade, sob a ótica das avaliações educacionais (Sistema de Avaliação da Educação Básica - Saeb; Programme for International Student Assessment - Pisa) e, na educação superior, serão analisados os efeitos do redesenho do Fies sobre as matrículas no setor privado. Em todos os casos, a intenção foi identificar possíveis implicaçóes para o alcance das metas do PNE 2014-2024.

Além da abordagem por níveis de ensino, faz-se o acompanhamento e análise do orçamento executado pelo MEC em 2015, tendo-se como referência os gastos realizados no ano anterior. Neste caso, chama atenção a redução dos dispêndios, sobretudo na educaçáo básica e na profissional e tecnológica.

\section{ACOMPANHAMENTO E ANÁLISE DO PNE}

\subsection{EDUCAÇÃO BÁSICA}

A educação básica é contemplada, no PNE 2014-2024, por cinco metas (1, 2, 3, 4 e 6) com foco na ampliação da oferta e, consequentemente, no acesso aos níveis de ensino que a integram. Os resultados educacionais são objeto de outras três metas (2, 5 e 7). Há ainda cinco metas relacionadas aos insumos (15 a 19), sendo que quatro delas referem-se aos profissionais da educação (formação dos professores e valorização da carreira docente) e uma última trata da gestão democrática nas escolas. Por fim, há duas metas (8 e 9) relacionadas com o aumento da escolaridade da população, e refletem os resultados alcançados, sobretudo, no âmbito da educação básica.

Ao longo desta seção, serão analisados os principais avanços identificados em 2015, e como tais resultados se situam em relação às metas do PNE 2014-2024.

\subsubsection{Sobre as metas de oferta/acesso}

Considera-se que há cinco metas sob esta categoria na educação básica, sendo que uma delas (meta 2) também versa sobre desempenho ou resultados educacionais. 
A meta 1 estabelece a universalização da pré-escola ( 4 e 5 anos) - identificada pelo indicador $1 \mathrm{~A}$ - e o atendimento em creches de pelo menos $50 \%$ das crianças de 0 a 3 anos - identificada pelo indicador $1 \mathrm{~B}$. A meta 2 refere-se à universalização do ensino fundamental de nove anos na faixa etária de 6 a 14 anos. A meta 3 também trata da universalização do atendimento aos jovens de 15 a 17 anos, bem como estipula o alcance da taxa de frequência líquida de $85 \%$ para esta faixa etária. Por sua vez, a meta 4 contempla o acesso universal à educação especial da população de 4 a 17 anos. Por fim, a meta 6 trata da oferta de educação em tempo integral em pelo menos $50 \%$ das escolas públicas, de modo a atender no mínimo $25 \%$ dos alunos matriculados na educação básica.

O Inep alterou a metodologia de cálculo dos indicadores de algumas dessas metas. Diferentemente do que havia sido divulgado no documento PNE - Linha de Base (Brasil. Inep, 2015), a data de corte para definição da idade em anos completos, utilizada na Pesquisa Nacional por Amostra de Domicílios (Pnad), do Instituto Brasileiro de Geografia e Estatística (IBGE), foi antecipada para 31 de março. De acordo com o Inep, essa alteraçáo da data de corte levou em conta o que estabelece a Resolução CNE/CEB no 06, de 21 de outubro de 2010, e as sugestóes provenientes da consulta pública (Portaria Inep no 424, de 9 de outubro de 2015) realizada em 2015 acerca dos indicadores que compunham o documento PNE - Linha de Base (Brasil. Inep, 2015). Com isso, houve elevação significativa dos índices apurados para quase todos os indicadores, conforme será apresentado ao longo desta seção.

a) Meta 1

$\mathrm{O}$ indicador $1 \mathrm{~A}$ da meta 1 trata da universalização do ensino à faixa etária de 4 a 5 anos. De fato, crianças pertencentes a essa faixa etária deveriam estar frequentando a pré-escola. Porém, de acordo com a Pnad 2015, havia cerca de $10 \%$ que ainda frequentavam creches.

Conforme pode ser observado no gráfico 1 , com a nova metodologia de cálculo da variável anos completos da Pnad, elevaram-se significativamente os índices relativos ao indicador $1 \mathrm{~A}$ ao longo do período 2005-2015, de modo que neste último ano, $91 \%$ das crianças dessa faixa etária frequentavam escola/ creche, tal como é mostrado no gráfico 1 . 
GRÁFICO 1

Percentual da população de 4 e 5 anos que frequentava escola ou creche - Brasil (2005-2015)

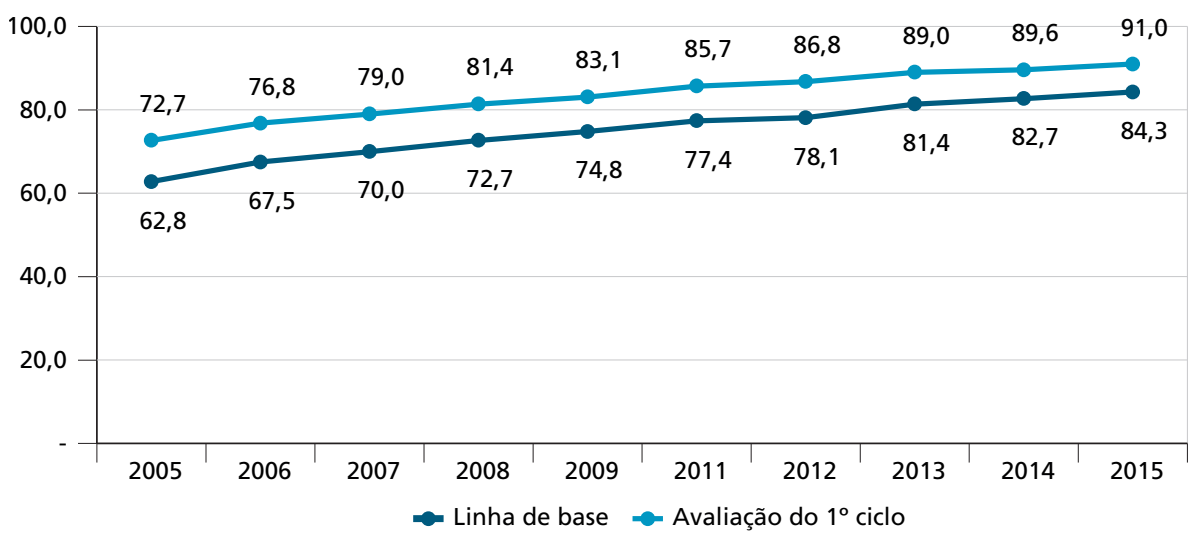

Fonte: Pnad/IBGE.

Elaboração: Disoc/lpea.

O retrospecto de crescimento desse indicador no período 2005-2015, da ordem de 2 pontos percentuais (p.p.) ao ano (a.a.) projeta como factível o alcance da meta de universalização até o final do PNE. Entretanto, o cumprimento dessa meta deveria ocorrer até 2016, o que certamente não se concretizará. Cabe lembrar que também a Lei no 12.796 , de 4 de abril de 2013, que regulamentou a Emenda Constitucional (EC) no 59, de 11 de novembro de 2009, e que instituiu a obrigatoriedade do ensino na faixa etária de 4 a 17 anos, deixará de ser cumprida. De qualquer modo, a universalização da frequência à escola das crianças de 4 e 5 anos constitui uma das mais promissoras metas de acesso à educação básica, que poderá ser atingida até o final da vigência do PNE 2014-2024.

No que se refere ao indicador $1 \mathrm{~B}$ da meta 1 , pode-se afirmar que as perspectivas não são tão favoráveis. Em primeiro lugar, porque o índice atingido em 2015 ainda está distante da meta de 50\%. Em grande medida, a dificuldade de se atingir esta proporção está relacionada com o fato de este nível de ensino não ser obrigatório. Além disso, por sua oferta ser uma atribuição dos entes municipais - estes, via de regra, evidenciam elevada fragilidade financeira, tanto para implantar a infraestrutura necessária, quanto para, principalmente, manter a oferta desse nível de ensino, que é tido como o mais oneroso da educação básica.

Desse modo, mesmo tendo sido favorecido pela nova metodologia de apuração, o indicador 1B registrou em 2015 decréscimo em relaçáo aos dois anos anteriores, conforme o gráfico 2 . 
GRÁFICO 2

Percentual da população de 0 e 3 anos que frequentava escola ou creche - Brasil (2005-2015)

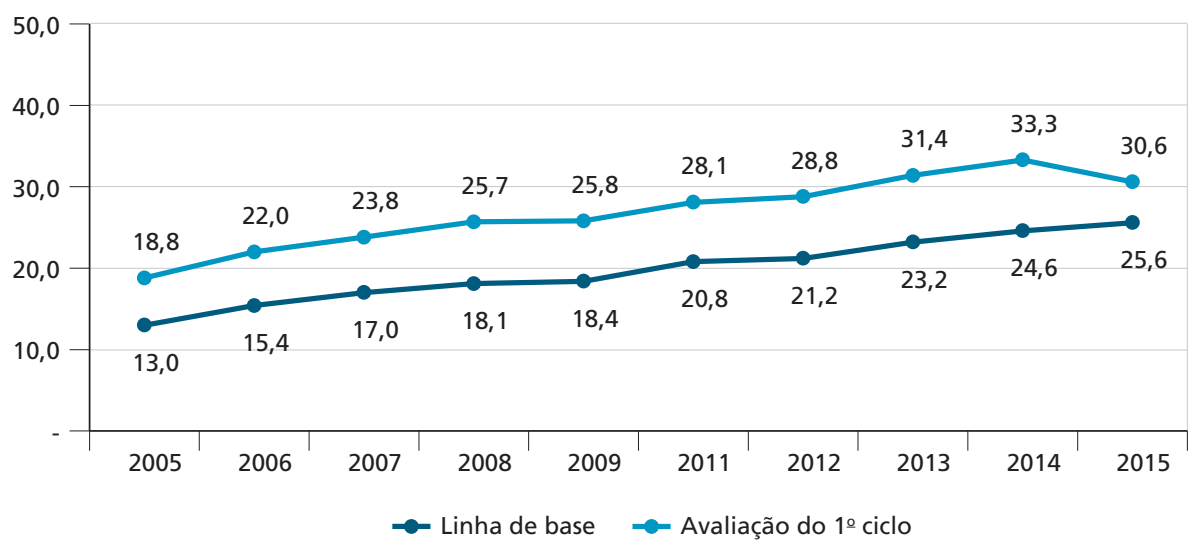

Fonte: Pnad/BGE.

Elaboração: Disoc/lpea.

De acordo com a nova fórmula de apuração do indicador 1B, o índice apurado em 2015 foi de 5 p.p. acima daquele obtido pela metodologia utilizada no documento linha de base do PNE. Portanto, tendo-se como horizonte o período de nove anos até o término da vigência do PNE, será necessário o incremento médio anual de 2,2 p.p. nesse indicador para que a referida meta de $50 \%$ seja alcançada em 2024. A título de comparação, a média de crescimento no período 2005-2015 foi de apenas 1,3 p.p.

Cabe lembrar que, no período 2010-2014, foram realizados vultosos investimentos do MEC na implantação de escolas de educação infantil, em convênio com os entes municipais. No entanto, a principal limitação para a ampliação da oferta de vagas reside nos elevados custos de manutenção dessas unidades escolares, sobretudo no que se refere ao pagamento de salários de professores e demais servidores.

Esse período de elevados investimentos na ampliação da rede de escolas foi interrompido em 2015, quando então foram transferidos aos entes municipais apenas $\mathrm{R} \$ 10$ milhōes, enquanto no ano anterior haviam sido repassados $\mathrm{R} \$ 2,9$ bilhôes, por intermédio da açâo Implantação de Escolas para Educação Infantil, conforme é apresentado na tabela 10, na subseção 2.4 - Financiamento e gastos.

Pressupondo-se que a tendência no médio prazo não aponta para a ampliação dos investimentos públicos nessa área, considera-se que a probabilidade de alcance da meta $1 \mathrm{~B}$ torna-se ainda menor. 


\section{b) Meta 2}

A meta 2 trata da universalização da frequência ao ensino fundamental de nove anos, na faixa etária de 6 a 14 anos. Trata-se de um desafio que poderá ser superado, em grande medida, pelo fato de a obrigatoriedade do ensino fundamental remontar à Constituição de 1967 e por ter sido reiterada pela Constituição Federal de 1988 (CF/88). Desse modo, investimentos e esforços adicionais vêm sendo direcionados a esse nível do ensino desde os anos 1990.

Com o novo método de cálculo desse indicador, houve ligeiro rebaixamento em relação aos índices apurados pela metodologia anterior. De todo modo, cerca de $98 \%$ das crianças nessa faixa etária frequentavam ou haviam concluído o ensino fundamental, o que aponta para sua virtual universalizaçáo.

GRÁFICO 3

Percentual da população de 6 a 14 anos que frequentava ou que havia concluído 0 ensino fundamental - Brasil (2005-2015)

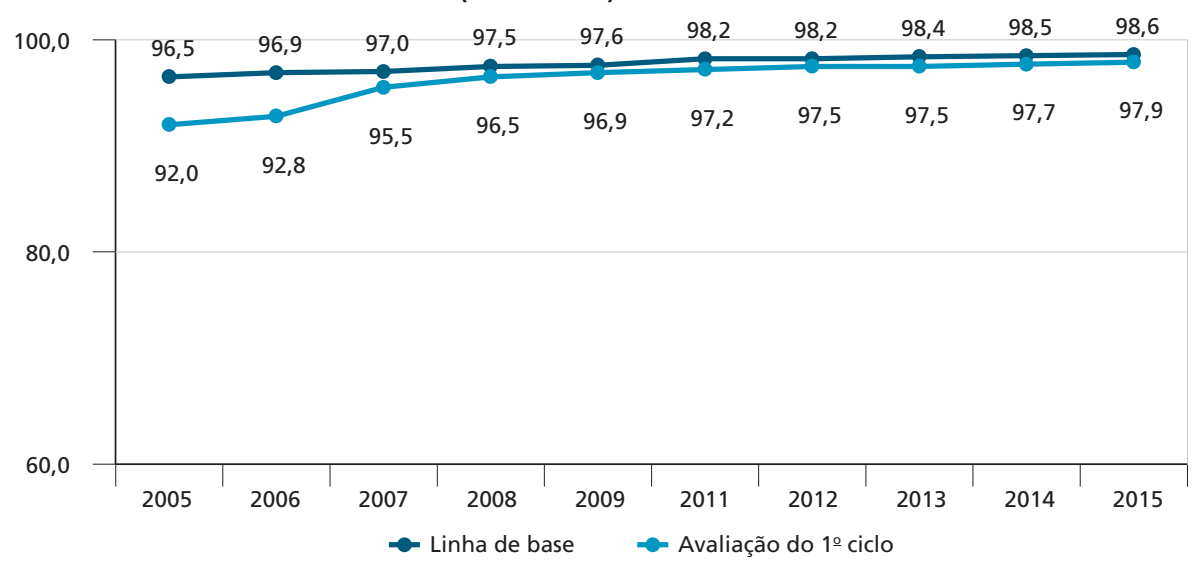

Fonte: Pnad/IBGE.

Elaboração: Disoc/lpea.

Conforme se observa no gráfico 3, sob qualquer um dos métodos utilizados para a apuração do referido indicador, obtêm-se resultados próximos em 2015. Pela nova forma de apuração do indicador, algo em torno de $2 \%$ da população nessa faixa etária não frequentava o ensino fundamental ou náo tinha concluído este nível de ensino até aquele ano. No entanto, caso fossem consideradas cerca de 182 mil crianças que frequentavam as modalidades maternal/jardim de infância, a taxa de frequência à escola chegaria a $98,6 \%$. 
O segundo indicador da meta 2 é o que mede a proporção de jovens de 16 anos que tenham concluído o ensino fundamental. Muito embora se trate de um indicador de resultado, optou-se por analisá-lo no corpo desta seção, visto que está estreitamente relacionado com a frequência ao ensino fundamental.

\section{GRÁFICO 4}

\section{Percentual da população de 16 anos que havia concluído o ensino fundamental - Brasil (2005-2015)}

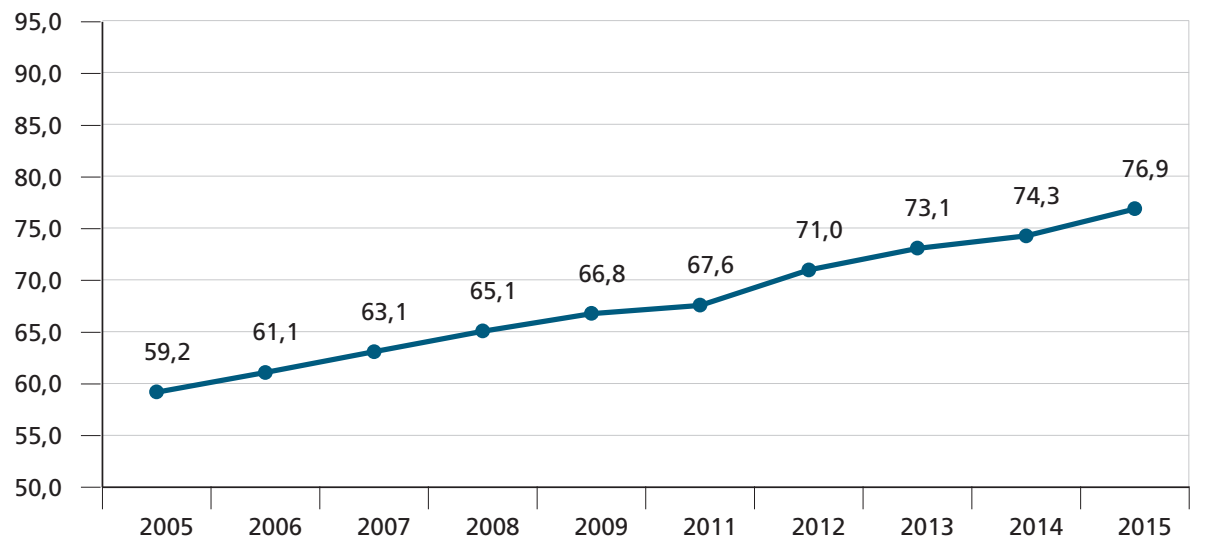

Fonte: Pnad/IBGE.

Elaboração: Disoc/lpea.

Conforme se observa no gráfico 4, a taxa de crescimento no período 2005-2015 foi expressiva, com incremento anual médio de 1,8 p.p. Caso seja mantido esse ritmo de expansão, torna-se factível o alcance da meta em 2024, considerando-se que a taxa de conclusão esperada para 2024 é de $95 \%$, o que implicaria um aumento anual médio de 2 p.p.

c) Meta 3

No que concerne à frequência à escola de jovens de 15 a 17 anos, foram estabelecidos dois indicadores no âmbito da meta 3. O primeiro indicador (3A), que mede a taxa de frequência à escola, foi ajustado para abranger aqueles que não frequentavam escola, mas que haviam concluído a educação básica. Por sua vez, o indicador $3 \mathrm{~B}$ compreende apenas os estudantes que frequentavam o nível de ensino adequado a esta faixa etária ou superior, bem como aqueles que haviam concluído a educação básica.

Em relação ao indicador $3 \mathrm{~A}$, cuja meta corresponde à universalização da frequência à escola até 2016, pode-se afirmar que tal intento não será atingido neste prazo e, dificilmente, até mesmo ao final da vigência do PNE 2014-2024, 
considerando-se a evolução deste indicador ao longo da última década, conforme o gráfico 5 .

\section{GRÁFICO 5}

Percentual da população de 15 a 17 anos que frequentava escola ou que havia concluído a educação básica - Brasil (2005 - 2015)

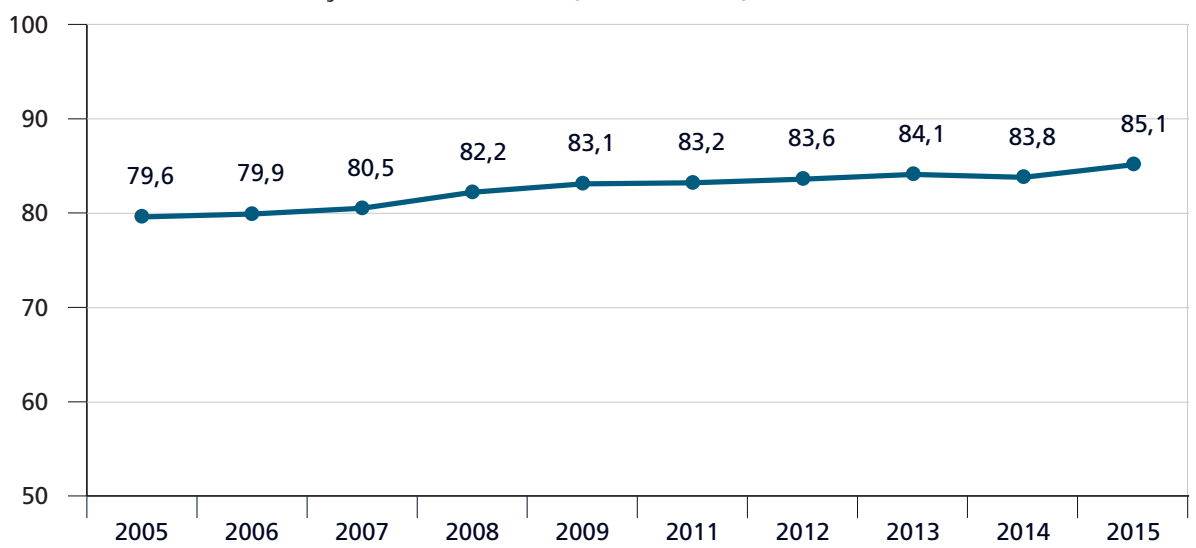

Fonte: Pnad/IBGE.

Elaboração: Disoc/lpea.

Ao longo do período 2005-2015, houve incremento de apenas 5,5 p.p. Portanto, não seria plausível supor que os cerca de 15 p.p. faltantes pudessem ser incorporados no prazo de nove anos. Além de o ritmo de crescimento necessitar ser praticamente triplicado, deve-se ter em conta que, à medida que se avança em direção à universalização, torna-se mais complexa a incorporação dos segmentos populacionais restantes, tendo em vista serem estes os mais vulneráveis.

O segundo indicador referente à meta 3 é o que mede a taxa de frequência líquida na faixa etária de 15 a 17 anos. Para o cálculo desse indicador, consideram-se todos os estudantes do ensino médio e também os que frequentam educação superior e cursos pré-vestibulares, bem como os jovens desta faixa etária que tenham concluído a educação básica.

Desse modo, o PNE 2014-2024 estabeleceu que, ao final de sua vigência, a taxa de frequência líquida na faixa etária de 15 a 17 anos deve atingir $85 \%$. Conforme mostra o gráfico 6, a proporçáo registrada em 2015 estava em torno de $67 \%$. 


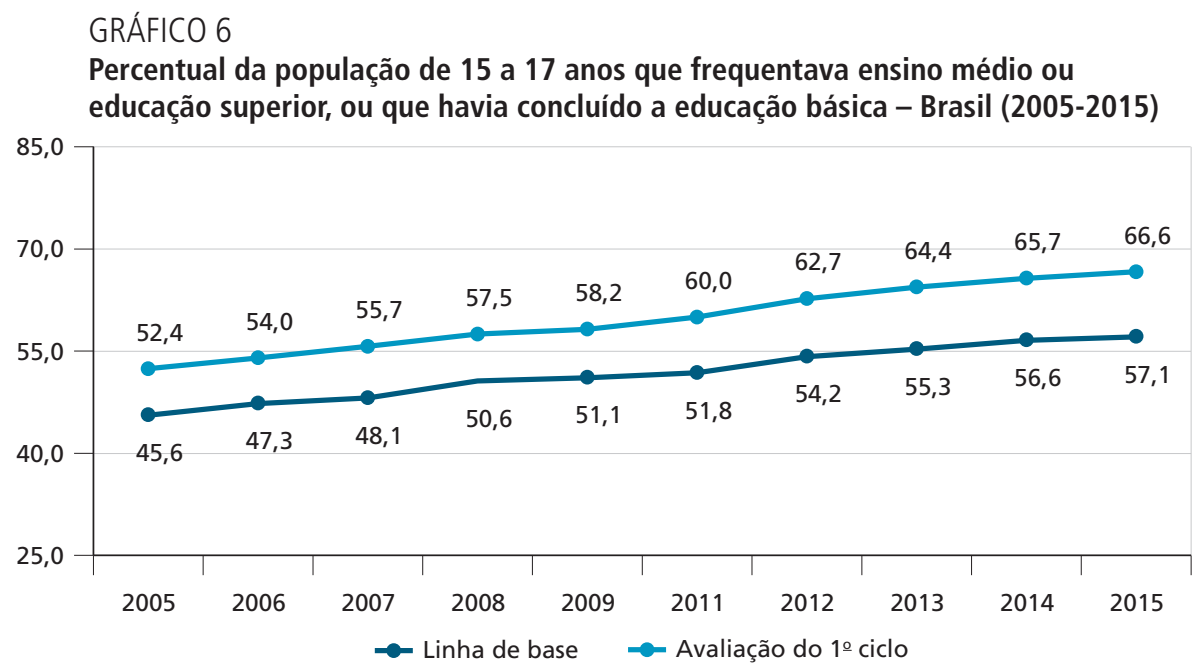

Fonte: Pnad/IBGE.

Elaboração: Disoc/lpea.

Em que pese ter havido significativa evoluçáo desse indicador no período sob análise, sobretudo quando se toma o novo método de apuração como parâmetro, da ordem de 1,4 p.p. ao ano, esforços adicionais serão necessários para incorporar cerca de 1,8 milhão de jovens de 15 a 17 anos que não frequentavam ou não haviam concluído o ensino médio, de modo a se atingir a meta estabelecida pelo PNE 2014-2024. ${ }^{1}$ Do contrário, e mantido o ritmo de crescimento dos últimos dez anos, a taxa a ser atingida ao final de sua vigência ficaria em torno de $80 \%$.

d) Meta 6

A ampliação do atendimento dos estudantes da educação básica em tempo integral constitui o foco da meta 6 . O primeiro indicador (6A) corresponde à proporção de estudantes atendidos nas redes públicas sob essa modalidade de ensino. $\mathrm{O}$ segundo indicador $(6 \mathrm{~B})$ diz respeito às escolas com a oferta de educação em tempo integral.

De acordo com os dados do Censo Escolar, realizado pelo Inep/MEC, o indicador $6 \mathrm{~A}$ apresentou evolução bastante acentuada ao longo dos últimos anos, o que apontava para uma perspectiva bastante favorável de cumprimento da meta de $25 \%$ dos alunos matriculados nas redes públicas, conforme é apresentado no gráfico 7 .

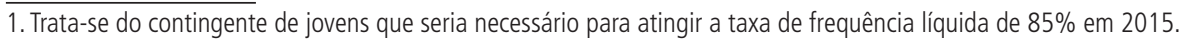


GRÁFICO 7

Percentual de matrículas da educação básica em tempo integral, nas redes públicas - Brasil (2009-2015)

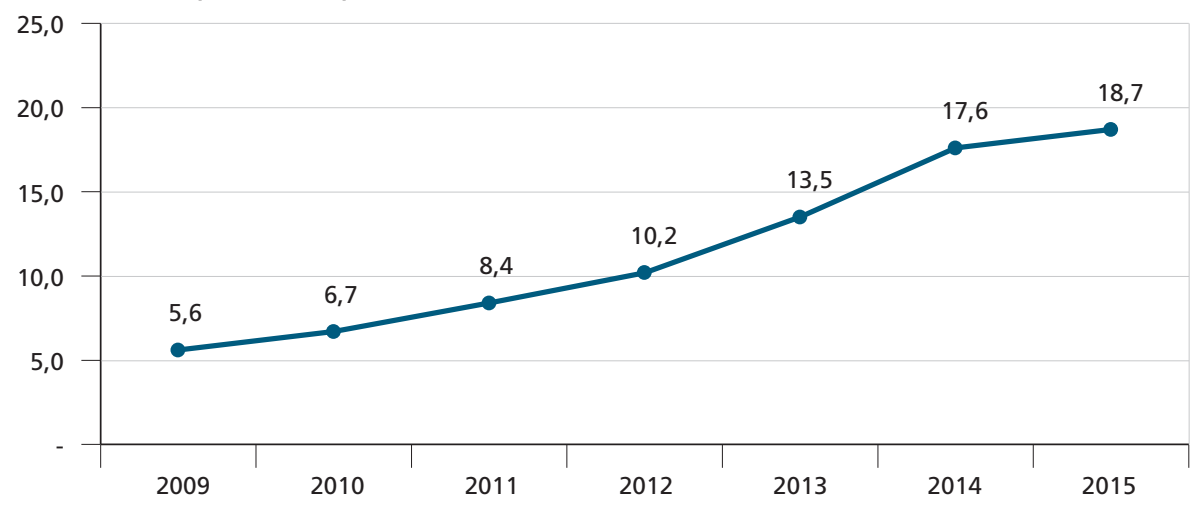

Fonte: Inep/MEC.

Elaboração: Disoc/lpea.

Esse crescimento expressivo foi possível graças à implantação do programa Mais Educação, instituído em 2007 por meio de Portaria Normativa Interministerial e regulamentado pelo Decreto $\mathrm{n}^{\mathrm{o}} 7.083 / 2010$, por meio do qual eram transferidos recursos financeiros para os entes federados, de modo a se "fomentar a educação integral de crianças, adolescentes e jovens, por meio do apoio a atividades socioeducativas no contraturno escolar" (Portaria Normativa Interministerial no 17/2007).

Apesar de ter viabilizado a ampliação do atendimento dos alunos em tempo integral, o Mais Educação foi criticado pelo fato de não ter contribuído para a melhoria da aprendizagem, tal como estabelecia o caput do art. $1^{\circ}$ do referido decreto: "O Programa Mais Educação tem por finalidade contribuir para a melhoria da aprendizagem por meio da ampliação do tempo de permanência de crianças, adolescentes e jovens matriculados em escola pública, mediante oferta de educação básica em tempo integral".

Acredita-se que, dificilmente, seria possível melhorar o desempenho dos alunos em português e matemática mediante a oferta de artes e esportes no contraturno escolar. No entanto, outras externalidades positivas poderiam advir do acesso a essas atividades - tais como aumento do interesse pelas atividades escolares e do próprio rendimento escolar, assim como a melhoria do convívio social e familiar -, evidenciadas pela avaliação do programa Segundo Tempo. ${ }^{2}$ 
Por sua vez, o indicador $6 \mathrm{~B}$, que se refere à proporção de escolas com ao menos um aluno com jornada escolar de pelo menos 7 horas, já havia superado a meta de $50 \%$ em 2014 , tendo atingido $52,5 \%$ das escolas no ano seguinte. Portanto, trata-se de uma meta que foi claramente subdimensionada, principalmente por ter considerado como requisito uma condição insatisfatória, ou seja, bastaria um único aluno para validar uma escola como ofertante de educação em período integral. Nesse sentido, o indicador $6 \mathrm{~B}$ pouco tem a ver com um desafio efetivo no âmbito do PNE, quando comparado aos indicadores das demais metas.

\subsubsection{Sobre as metas de resultados educacionais}

O PNE 2014-2024 contempla quatro metas de resultados educacionais. A primeira delas (meta 5) refere-se à alfabetização de crianças até o final do $3^{\circ}$ ano do ensino fundamental. Em seguida, a meta 7 incorporou as metas do Ideb formuladas por intermédio do Plano de Desenvolvimento da Educação (PDE), instituído pelo MEC em 2007. A meta 8 trata da escolaridade média da população jovem (18 a 29 anos) e, por fim, a meta 9 refere-se à alfabetização da população de 15 anos ou mais.

e) Meta 5

Com relação à meta 5 , deve-se salientar que não foi definido um indicador para o seu monitoramento. Os dois relatórios sobre o PNE 2014-2024, produzidos pelo Inep, apresentam os resultados da Avaliação Nacional da Alfabetização (ANA), por níveis de proficiência, mas sem definir o nível a partir do qual seria considerado aceitável.

No relatório de avaliação do primeiro ciclo do PNE 2014-2024, faz-se a diferenciação entre o que se entende por alfabetização e letramento. De acordo com o Inep, "alfabetização pode ser definida como a apropriação do sistema de escrita, que pressupõe a compreensão do princípio alfabético, indispensável ao domínio da leitura e da escrita. O letramento, por sua vez, é definido como prática e uso social da leitura e da escrita em diferentes contextos". ${ }^{3}$

Sob essa abordagem, é possível observar a distribuição dos resultados de desempenho dos estudantes brasileiros em escrita, leitura e matemática. No primeiro caso, foi utilizada uma escala em cinco níveis de proficiência e nos demais apenas quatro níveis, cujos resultados desagregados por macrorregióes são apresentados no gráfico 8 . 


\section{GRÁFICO 8}

Distribuição percentual dos estudantes por níveis de proficiência em escrita na ANA - Brasil e macrorregiões (2014)

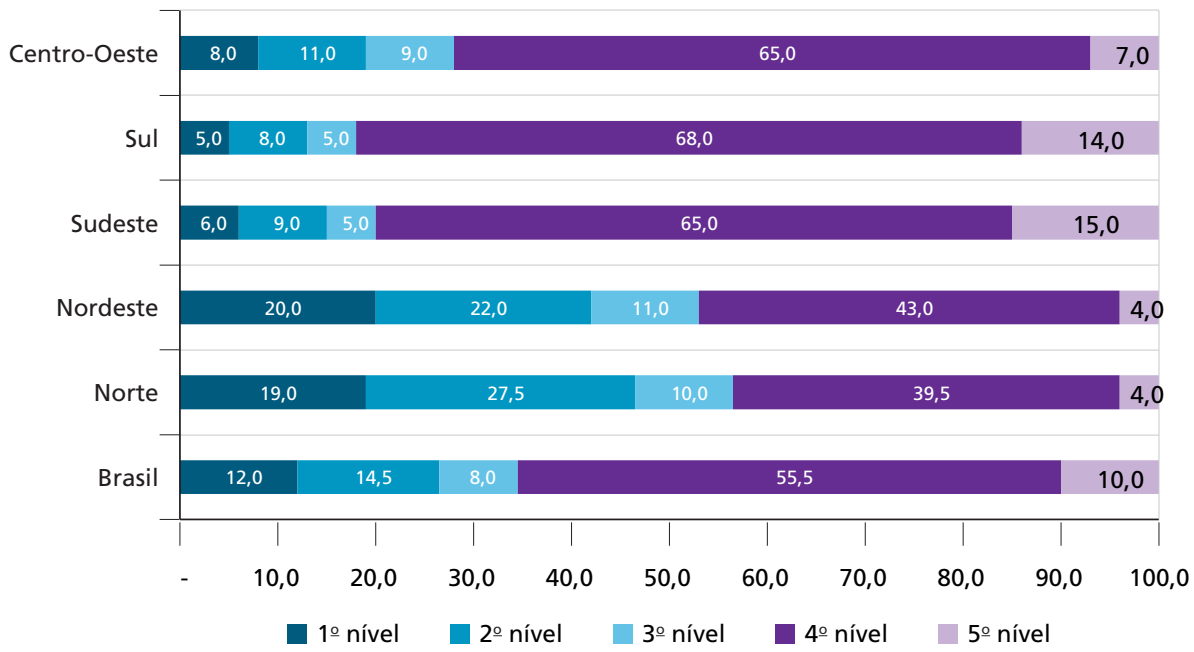

Fonte: Inep/MEC.

Elaboração: Disoc/lpea.

O gráfico 8 mostra a desigualdade entre as macrorregióes brasileiras. De um lado, Norte e Nordeste, com mais da metade dos estudantes nos três níveis iniciais. De outro, as regiôes mais ricas do país, Sul e Sudeste, com menos de $20 \%$ de seus alunos nesses mesmos níveis. Por fim, em posição intermediária, situa-se a regiáo Centro-Oeste, ainda que mais próxima das regióes mais ricas.

Tendência semelhante pode ser observada na proficiência em leitura e matemática que, nestes casos, são avaliadas por meio de uma escala com quatro níveis de desempenho. A despeito de haver maior equilíbrio na distribuição dos alunos entre os dois primeiros níveis e os dois últimos, ainda assim se observa que, nas regióes Norte e Nordeste, predominam os dois níveis inferiores, enquanto o contrário se verifica no Sul e no Sudeste. Além disso, chama a atenção o fato de a distribuição dos estudantes nesses dois níveis ser bastante similar em ambas as disciplinas, conforme é mostrado no gráfico 9 . 
GRÁFICO 9

Distribuição percentual dos estudantes por níveis de proficiência em leitura e matemática na ANA - Brasil e macrorregiões (2014)

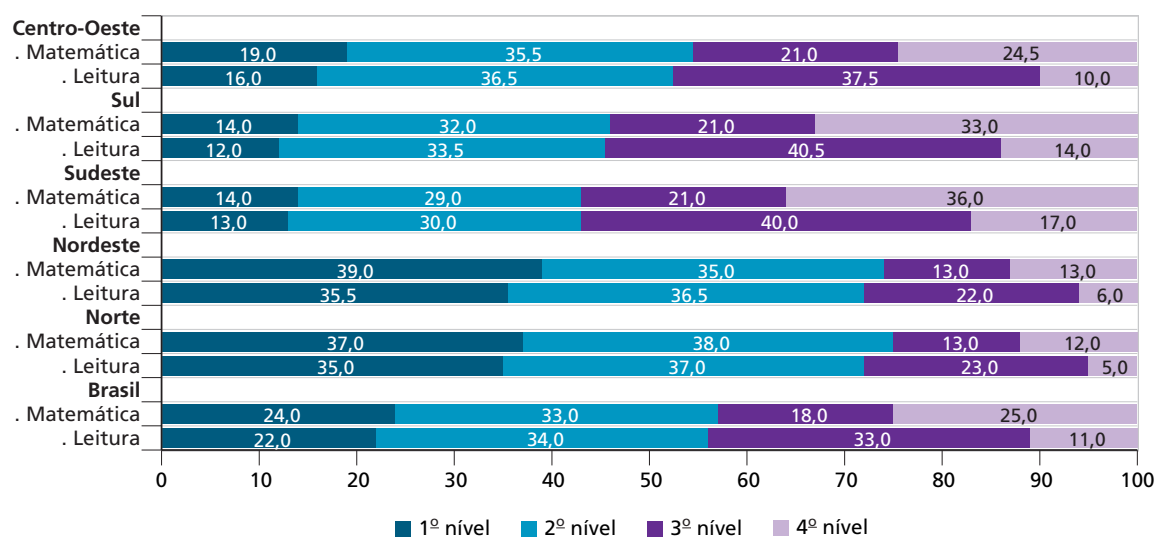

Fonte: Inep/MEC.

Elaboração: Disoc/lpea.

Portanto, tendo-se como parâmetro as escalas de proficiência da ANA, havia $12 \%$ dos estudantes do $3^{\circ}$ ano do ensino fundamental das escolas públicas avaliados com domínio insuficiente em escrita e cerca do dobro dessa proporção com proficiência precária em leitura e matemática. Porém, há ausência de equivalência entre esses níveis iniciais, pois no primeiro nível da escala em leitura o aluno já é capaz de ler palavras de forma separada, enquanto no primeiro nível em escrita encontram-se estudantes incapazes de escrever corretamente sequer uma palavra. Desse modo, a utilização dos resultados da ANA para o monitoramento da meta 5 do PNE carece de uma definição objetiva em termos dos níveis minimamente aceitáveis.

De modo alternativo, pode-se realizar esse monitoramento por intermédio da Pnad, tendo-se como unidade de análise os estudantes que frequentam o $3 \circ$ ano do ensino fundamental ou, então, as crianças de 8 anos de idade.

No primeiro caso, seria mais adequado utilizar a idade de coleta da Pnad, que é realizada no mês de setembro e, portanto, mais próxima do término do ano letivo. Por este motivo, o mesmo critério se aplicaria à apuração do indicador com base na idade da criança.

De acordo com a Pnad 2015, havia cerca de 3,2 milhóes de pessoas que frequentavam o terceiro ano do ensino fundamental, mas quase $48 \%$ tinham idade acima de 8 anos. Desse universo de pessoas, 93,5\% sabiam ler e escrever, sendo que a proporção entre aquelas com 8 anos de idade ampliava-se para 94,7\%. Por sua vez, a taxa de alfabetização caía para $91,4 \%$ entre os estudantes de 8 anos que frequentavam o ensino fundamental e para $90,3 \%$ do total das crianças com esta idade. 


\section{f) Meta 7}

Em que pese o senso comum reinante acerca da baixa qualidade da educação brasileira, os dados do Índice de Desenvolvimento da Educação Básica (Ideb) relativos a 2015 reiteram a tendência de melhoria, delineada desde a criação deste indicador, ao menos no que se refere aos anos iniciais do ensino fundamental.

Essa evolução será aqui analisada segundo dois enfoques. Em ambos os casos, têm-se como unidades de análise o município e as redes públicas de ensino em seu conjunto. Sob o primeiro enfoque, tomou-se como referência de qualidade mínima aceitável a meta de 6,0 pontos a ser alcançada até 2024 . Neste caso, foi estabelecida uma escala de pontuação, correspondente a quatro conceitos, a saber: i) inferior $(<4,0)$; ii) médio-inferior $(\geq 4,0<5,0)$; iii) médio-superior $(\geq 5,0<$ $6,0)$; e $i v)$ superior $(\geq 6,0)$.

Tomando-se o período 2009-2015, verifica-se que houve redução significativa da proporção de municípios com Ideb na categoria inferior e aumento quase que equivalente na categoria superior, conforme é mostrado na tabela 1. No entanto, não foi observada oscilação significativa nas categorias intermediárias que, juntas, responderam por cerca de 59\% dos municípios brasileiros. De qualquer modo, nesse período de seis anos houve inversão na proporção de municípios abrangidos pelas duas categorias inferiores em comparação com as duas superiores. Se em 2009 as duas primeiras respondiam por $66 \%$ do total, em 2015 os municípios com nota maior ou igual a 5,0 pontos correspondiam a $64 \%$ do total.

TABELA 1

Distribuição percentual do Ideb dos anos iniciais do ensino fundamental, por estratos selecionados - Brasil (2009-2015)

\begin{tabular}{lcccc}
\hline Ideb & 2009 & 2011 & 2013 & 2015 \\
\hline$<4,0$ & 33,4 & 23,4 & 20,3 & 9,3 \\
$\geq 4,0<5,0$ & 29,7 & 29,1 & 23,2 & 26,7 \\
$\geq 5,0<6,0$ & 29,4 & 33,9 & 34,6 & 32,0 \\
$\geq 6,0$ & 7,5 & 13,6 & 21,8 & 32,1 \\
\hline
\end{tabular}

Fonte: Inep/MEC.

Elaboração: Disoc/lpea.

Um segundo enfoque de análise tem por parâmetro a meta intermediária referente a 2015, estabelecida para cada município brasileiro e, neste caso, para o conjunto das redes públicas. Desse modo, o objetivo foi o de identificar a proporção de municípios que haviam atingido suas respectivas metas.

Sob o parâmetro das metas intermediárias, pode-se afirmar que os resultados são ainda melhores. Neste caso, cerca de $76 \%$ dos municípios brasileiros haviam 
atingido ou superado a meta estabelecida para 2015. Apesar disso, esse avanço não ocorreu de forma homogênea em termos regionais. Por exemplo, na região Norte esse índice foi de apenas 57\%, enquanto no conjunto das regióes Sul, Sudeste e Centro-Oeste a proporção atingiu cerca de $83 \%$.

Desigualdades dessa natureza também podem ser observadas dentro de uma mesma região. Por exemplo, o Ceará se destaca no Nordeste, ao registrar 100\% de sucesso nesse quesito. Por sua vez, nos demais estados desta região, apenas dois terços dos municípios lograram esse êxito.

Em relação ao ensino médio, pode-se afirmar que os avanços em termos de proficiência foram muito pequenos, no caso das redes estaduais, e até negativo na rede privada, quando se tem por referência o desempenho dos estudantes na Avaliação Nacional da Educação Básica (Aneb), que integra o Saeb, ${ }^{4}$ conforme é mostrado na tabela 2.

TABELA 2

Nota média padronizada no Saeb (ensino médio), por redes de ensino selecionadas Brasil (2005-2015)

\begin{tabular}{lccccccc}
\hline Rede de ensino & 2005 & 2007 & 2009 & 2011 & 2013 & 2015 & $\begin{array}{c}\text { Variação } \\
\%\end{array}$ \\
\hline Estadual & 4,06 & 4,18 & 4,34 & 4,32 & 4,19 & 4,24 & 4,4 \\
Privada & 5,96 & 5,90 & 5,96 & 6,05 & 5,79 & 5,64 & $-5,4$ \\
\hline
\end{tabular}

Fonte: Inep/MEC.

Elaboração: Disoc/lpea.

Obs.: Nota padronizada entre as pontuações médias nas provas de língua portuguesa e matemática.

Os dados da tabela 2 também evidenciam a profunda desigualdade de desempenho entre os estudantes das redes estaduais e os da rede privada. Em grande medida, tais diferenças estão relacionadas às distintas origens e condições socioeconômicas desses estudantes. Portanto, o nível de competências adquiridas pelos egressos do ensino médio público, pertencentes aos estratos de renda inferiores, estaria aquém daquele alcançado pelos egressos pertencentes aos estratos de renda mais altos.

\footnotetext{
4. "O Sistema de Avaliação da Educação Básica - Saeb, instituído em 1990, é composto por um conjunto de avaliações externas em larga escala e tem como principal objetivo realizar um diagnóstico da educação básica brasileira e de alguns fatores que possam interferir no desempenho do estudante, fornecendo um indicativo sobre a qualidade do ensino ofertado" (Inep). Em 2005, o Saeb foi reestruturado e passou a ser composto por duas avaliações: a Avaliação Nacional da Educação Básica (Aneb), que manteve as características, os objetivos e os procedimentos da avaliação efetuada até aquele momento pelo Saeb, e a Avaliação Nacional do Rendimento Escolar (Anresc), conhecida como Prova Brasil, criada com o objetivo de avaliar a qualidade do ensino ministrado nas escolas das redes públicas. Em 2013, a Avaliação Nacional da Alfabetização (ANA) foi incorporada ao Saeb para melhor aferir os níveis de alfabetização e letramento em Língua Portuguesa (leitura e escrita) e Matemática". (Texto extraído da página do Inep na internet. Disponível em: <http://portal.inep.gov.br/web/guest/educacao-basica/saeb >.).
} 
De qualquer modo, esses dados indicam que não é promissora a evolução da proficiência dos estudantes brasileiros, inclusive entre aqueles que correspondem ao segmento que conseguiu superar obstáculos e processos excludentes que permeiam a trajetória escolar de grande parcela dos jovens brasileiros.

Por outro lado, observa-se que no ensino fundamental houve aumento significativo da proficiência ao longo do mesmo período, o que levaria a crer que estudantes mais bem preparados estariam ingressando no ensino médio (tabela 3).

TABELA 3

Nota média padronizada na Prova Brasil (anos finais), por redes de ensino - Brasil (2005-2015)

\begin{tabular}{lccccccc}
\hline Rede de ensino & 2005 & 2007 & 2009 & 2011 & 2013 & 2015 & $\begin{array}{c}\text { Variação } \\
\%\end{array}$ \\
\hline Pública & 4,28 & 4,49 & 4,67 & 4,73 & 4,72 & 4,97 & 16,1 \\
Privada & 6,15 & 6,14 & 6,21 & 6,34 & 6,25 & 6,35 & 3,3 \\
\hline
\end{tabular}

Fonte: Inep/MEC.

Elaboração: Disoc/lpea.

Obs.: Nota padronizada entre as pontuações médias nas provas de língua portuguesa e matemática.

A melhoria de desempenho dos estudantes das redes públicas foi considerável. Em termos relativos, maior que a dos estudantes da rede privada, muito embora se saiba que incrementos maiores são possíveis quando o nível de desempenho é mais baixo.

Em que pese ter sido positiva a evolução da proficiência nos anos iniciais do ensino fundamental, os resultados dos ciclos escolares seguintes ainda são insuficientes, quando se tem em conta aqueles observados em economias mais desenvolvidas. É preciso reconhecer que existe um elevado número de alunos que não consegue atingir os níveis de proficiência esperados para as últimas etapas da educação básica.

A despeito de todas as limitaçóes existentes em termos de diferenças culturais, territoriais e de formas da organização da economia e da sociedade, a comparação com outros países possibilita a identificação de aspectos ou áreas em que a situação do Brasil se mostra mais crítica.

Nesse sentido, a evolução do desempenho no Pisa, coordenado pela Organização para a Cooperação e Desenvolvimento Econômico (OCDE), é a que serve de base para comparar os estudantes brasileiros com os de outros países. Inicialmente, o gráfico 10 apresenta os resultados do Brasil desde 2000 para cada componente do exame, ou seja, matemática, leitura e ciências, para alunos de 15 anos de idade, cuja média aritmética resulta na média geral do Pisa. 
GRÁFICO 10

Notas médias dos estudantes brasileiros no Pisa por disciplina e média geral (2000-2015)

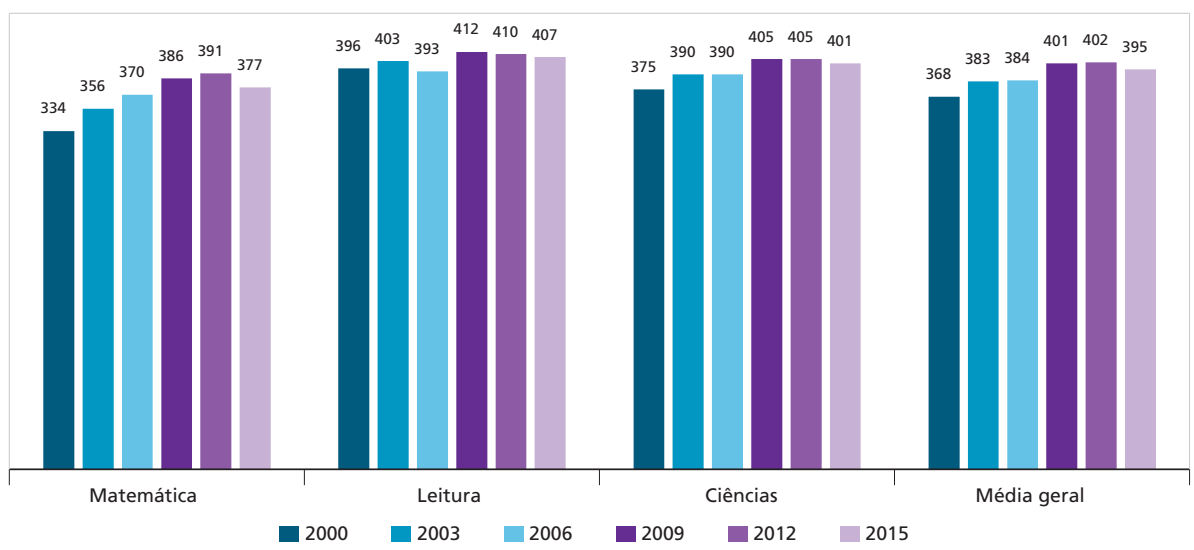

Fonte: OCDE, apud Inep (2016).

Ao se analisarem os resultados do Pisa no gráfico 10, é possível perceber-se uma evolução positiva entre 2000 e 2015, com avanço mais destacado em matemática e menos evidente em leitura e ciências. O recuo de notas em 2015 foi observado para a grande maioria dos países que participaram do Pisa e não revela, em princípio, uma piora brasileira em termos de desempenho. Nas próximas ediçóes, será possível observar esse fenômeno com mais atenção.

Ao se comparar uma amostra de países selecionados ${ }^{5}$ na tabela 4 , verifica-se que o Brasil possui os piores resultados em todas as disciplinas, ou seja, a maior proporção de notas inferiores a 2, que representa o mínimo necessário. Ao se comparar as notas brasileiras com as de todos os países participantes do Pisa, elas não são as piores, mas estão entre as de mais baixo desempenho desde o começo da aplicaçẫo do teste. Não é possível falar em melhoria no ranking, pois o Pisa 2015 contou com um maior número de países participantes que a edição anterior, o que dificulta essa comparação.

\footnotetext{
5. Os resultados apresentados em OCDE (2016) não incluíram todos os países que participaram do Pisa, o que limitou muito as possibilidades de comparação. Assim, não existiam resultados para os BRICS (Brasil, Rússia, Índia, China e África do Sul) ou Argentina. 0 mesmo vale para a Suécia e a Alemanha, que, junto aos Estados Unidos (país selecionado), são casos paradigmáticos de modelos de políticas sociais. Para substituir a Alemanha, a alternativa foi escolher Portugal, e para substituir a Suécia, a escolha foi a Finlândia, o único país escandinavo disponível. A escolha da Coreia do Sul foi a alternativa disponível para destacar um país do Sudeste Asiático com bons resultados no Pisa. Chile, Colômbia e México são países latino-americanos, tendo sido selecionados entre os mais populosos ou com instituições mais amadurecidas.
} 
TABELA 4

Distribuição percentual dos estudantes por nível de pontuação no Pisa, para países selecionados (2015)

\begin{tabular}{|c|c|c|c|c|c|c|c|c|c|}
\hline \multirow{2}{*}{ País } & \multicolumn{3}{|c|}{ Ciências } & \multicolumn{3}{|c|}{ Leitura } & \multicolumn{3}{|c|}{ Matemática } \\
\hline & Até 2 & 2 a 5 & 5 e 6 & Até 2 & 2 a 5 & 5 e 6 & Até 2 & 2 a 5 & 5 e 6 \\
\hline Chile & 34,8 & 63,9 & 1,2 & 28,4 & 69,4 & 2,3 & 49,4 & 49,3 & 1,4 \\
\hline Colômbia & 49,0 & 50,6 & 0,3 & 42,8 & 56,2 & 1,0 & 66,3 & 33,4 & 0,3 \\
\hline Coreia do Sul & 14,4 & 75,0 & 10,6 & 13,7 & 73,7 & 12,7 & 15,5 & 63,6 & 20,9 \\
\hline Estados Unidos & 20,3 & 71,2 & 8,5 & 19,0 & 71,4 & 9,6 & 29,4 & 64,7 & 5,9 \\
\hline Finlândia & 11,5 & 74,2 & 14,3 & 11,1 & 75,2 & 13,7 & 13,6 & 74,8 & 11,7 \\
\hline México & 47,8 & 52,1 & 0,1 & 41,7 & 57,9 & 0,3 & 56,6 & 43,0 & 0,3 \\
\hline Portugal & 17,4 & 75,2 & 7,4 & 17,2 & 75,2 & 7,5 & 23,8 & 64,8 & 11,4 \\
\hline Brasil & 56,6 & 42,7 & 0,7 & 51,0 & 47,6 & 1,4 & 70,3 & 28,9 & 0,9 \\
\hline
\end{tabular}

Fonte: OCDE, apud Inep (2016).

O desempenho do Brasil assemelha-se ao de países vizinhos e de outros que não se inserem na categoria de renda elevada. A dimensão territorial e a heterogeneidade social explicam, em grande medida, esse resultado. De modo semelhante, percebe-se que o desempenho dos Estados Unidos é inferior ao de países ricos de menor dimensão territorial e desigualdade social, tais como Finlândia e Coreia do Sul, o que leva a crer que esses fatores estejam interferindo nos resultados do Pisa.

$\mathrm{O}$ aspecto mais interessante do Pisa é a possibilidade de serem efetuadas comparaçóes internacionais. No entanto, o Pisa não se restringe aos resultados dos testes e dispóe de respostas a detalhados questionários para se verificar a situação do ensino em diversos países. A tabela 5 apresenta dados relevantes sobre frequência e repetência que caracterizam o cenário de cada país e permitem situar o Brasil nesse contexto.

TABELA 5

Percentual de alunos que declararam ter atraso, faltas nas duas semanas anteriores ao exame e repetência em ciclos de ensino, em países selecionados (2015)

\begin{tabular}{lcccccccc}
\hline \multirow{2}{*}{ País } & \multicolumn{3}{c}{ Atrasos ou faltas nos últimos quinze dias } & & \multicolumn{3}{c}{ Repetência nos ciclos } \\
\cline { 2 - 3 } & Atrasos & $\begin{array}{c}\text { Faltaram em aulas } \\
\text { específicas }\end{array}$ & $\begin{array}{c}\text { Faltou um dia } \\
\text { inteiro }\end{array}$ & & $\begin{array}{c}\text { Fund. } \\
\text { Inicial }\end{array}$ & Fund. Final & $\begin{array}{c}\text { Ensino } \\
\text { Médio }\end{array}$ \\
\hline Chile & 14,4 & 4,0 & 2,2 & & 14,5 & 6,8 & 7,5 \\
Colômbia & 6,8 & 7,0 & 6,4 & & 23,0 & 30,6 & 2,6 \\
Coreia do Sul & 3,4 & 0,7 & 0,5 & & 4,3 & 4,1 & 3,0 \\
Estados Unidos & 5,9 & 7,1 & 6,3 & & 8,9 & 3,2 & 1,3 \\
Finlândia & 6,9 & 10,1 & 9,5 & & 2,6 & 0,7 & 0,0 \\
México & 7,4 & 3,8 & 3,8 & & 12,2 & 4,2 & 0,6 \\
Portugal & 7,9 & 6,4 & 3,8 & & 16,8 & 21,5 & 0,2 \\
Brasil & 6,5 & 9,9 & 10,0 & & 20,3 & 20,1 & 6,5 \\
\hline
\end{tabular}


Ao se analisarem os dados da tabela 5, foi possível verificar que o Brasil, segundo o relato dos seus alunos, não liderou o ranking do atraso na chegada às aulas. Mas, quando o assunto é a ausência a uma aula específica ou ao longo de um dia inteiro, a situação muda, e os resultados brasileiros passam a ser os piores. Em termos de ausência a uma aula específica, os alunos brasileiros tiveram resultados elevados, sendo superados apenas pelos finlandeses. Não existem informaçóes relatando se outras atividades escolares são responsáveis por esse tipo de falta. Alunos brasileiros e finlandeses tiveram ausências em aulas específicas ou ao longo do dia de cerca de $10 \%$, o que é muito elevado em comparação aos demais países.

A tabela 5 ainda trata da repetência nos diferentes ciclos do ensino, segundo as informaçóes fornecidas pelos alunos que participaram do Pisa em 2015, ou seja, anos iniciais e finais do fundamental e do ensino médio. Nesse quesito, o Brasil apresenta índices superiores aos da maioria dos países. Apenas Colômbia, no ensino fundamental, e Chile, no ensino médio, têm resultados piores que os do Brasil. Os resultados não revelam se essa repetência está associada à evasão ou a problemas relativos ao aprendizado em disciplinas específicas.

Em relação à opinião e percepção dos alunos, existem outros aspectos a destacar, conforme aponta a tabela 6 .

TABELA 6

Percentual de alunos participantes do Pisa que relataram haver problemas que dificultavam a realização de atividades em sala de aula, por países selecionados (2015)

\begin{tabular}{lccccc}
\hline País & $\begin{array}{c}\text { Alunos que } \\
\text { não respeitam } \\
\text { professores }\end{array}$ & $\begin{array}{c}\text { Consumo de álcool } \\
\text { ou substâncias } \\
\text { ilegais }\end{array}$ & $\begin{array}{c}\text { Molestar outros } \\
\text { alunos }\end{array}$ & $\begin{array}{c}\text { Falta de } \\
\text { assiduidade de } \\
\text { professores }\end{array}$ & $\begin{array}{c}\text { Despreparo dos } \\
\text { professores }\end{array}$ \\
\hline Chile & 20,8 & 22,5 & 13,6 & 35,4 & 29,4 \\
Colômbia & 22,9 & 16,2 & 16,1 & 19,8 & 12,1 \\
Coreia do Sul & 33,0 & 13,5 & 8,4 & 2,0 & 10,3 \\
Estados Unidos & 18,4 & 19,0 & 14,0 & 17,0 & 13,3 \\
Finlândia & 32,5 & 4,5 & 23,0 & 15,9 & 6,4 \\
México & 10,6 & 16,9 & 16,1 & 14,1 & 10,7 \\
Portugal & 31,1 & 7,5 & 7,4 & 11,2 & 7,8 \\
Brasil & 45,1 & 21,2 & 17,2 & 32,6 & 28,9 \\
\hline
\end{tabular}

Fonte: OCDE apud Inep (2016).

Obs.: Os resultados desta tabela associam as alternativas em que os alunos consideraram os quesitos como muito ou até certo ponto em suas respostas aos questionários do Pisa.

As informaçôes da tabela 6 podem ser subdivididas em dois grupos: o primeiro, centrado na postura dos alunos; e o segundo, em sua avaliação em relação aos professores. Nos dois grupos, os resultados brasileiros figuram entre os piores, 
representando um problema para a trajetória escolar dos alunos. A questão inicial se relaciona ao respeito dos alunos em relação aos professores. Mais de $45 \%$ dos alunos brasileiros relatam haver falta de respeito dos alunos para com os professores, sendo esse o pior resultado entre os países selecionados. Esse resultado é bem superior ao dos demais países, onde o problema também requer atenção. Em relação ao consumo de álcool ou substâncias ilegais, os resultados brasileiros são superados somente pelos chilenos, sendo elevado também em todos os países de nosso continente. O Brasil também apresenta elevada proporção no quesito "molestar outros alunos", sendo superado pela Finlândia nesse caso. Essas questóes não apresentam perguntas específicas sobre os conceitos de desrespeito ou sobre o que é molestar.

A avaliação dos alunos em relação à assiduidade e ao preparo dos professores para o ofício também é negativa, sendo superada somente pelo caso chileno. Para os demais países, o problema existe, mas a sua incidência é bem menor. Os resultados apresentados para o Brasil comprovam a importância do PNE, ao buscar, nas metas 15, 16, 17 e 18, melhorar as condiçóes de trabalho dos professores, nos aspectos seguintes, a serem atingidos até 2024: formação inicial mínima requerida, formação continuada, melhoria salarial e consolidaçáo de planos de carreira. Esses aspectos são determinantes para atrair profissionais mais bem qualificados, retendo-os na carreira e reforçando os mecanismos que mantenham a motivação em patamares elevados.

Em relação às respostas dos alunos para o Pisa, existem aquelas que relatam as condiçóes existentes em suas residências, com vistas a estudar e consolidar o que foi exposto na escola (tabela 7).

TABELA 7

Percentual de alunos, em países selecionados, que relataram dispor de condições favoráveis para estudar em casa

\begin{tabular}{lcccc}
\hline País & Próprio quarto & Lugar para estudar & Computador & $\begin{array}{c}\text { Softwares } \\
\text { educativos }\end{array}$ \\
\hline Chile & 81,8 & 86,1 & 83,5 & 32,4 \\
Colômbia & 65,9 & 69,8 & 62,6 & 27,5 \\
Coreia do Sul & 79,7 & 84,5 & 91,1 & 51,3 \\
Estados Unidos & 86,8 & 89,7 & 87,5 & 68,2 \\
Finlândia & 94,3 & 95,4 & 95,8 & 40,0 \\
México & 51,5 & 73,0 & 56,5 & 24,2 \\
Portugal & 81,4 & 96,3 & 95,9 & 45,3 \\
Brasil & 75,0 & 79,1 & 69,4 & 30,4 \\
\hline
\end{tabular}

Fonte: OCDE apud Inep (2016).

A tabela 7 apresenta informações sobre as condições para estudar no domicílio que podem ser subdivididas em duas categorias: condiçôes físicas da residência; e 
disponibilidade de computadores e softwares para o estudo. No caso das residências, três em cada quatro estudantes brasileiros do ensino médio afirmam dispor do seu próprio quarto, ou seja, estão em melhores condiçóes que os colombianos e, sobretudo, os mexicanos, não apresentando resultados muito inferiores aos dos países desenvolvidos. Quanto à disponibilidade de espaços para estudo, quase quatro em cinco estudantes brasileiros relataram existirem condiçōes dessa natureza em suas residências, ou seja, os resultados são melhores do que para colombianos e mexicanos, e não se distanciam muito daqueles dos países mais desenvolvidos.

No que diz respeito à disponibilidade de computadores e softwares educativos, a condição brasileira também é melhor que a colombiana ou mexicana, sendo inferior à chilena no primeiro caso. Ainda assim, quase sete em cada dez alunos declararam possuir computadores, o que náo se distancia muito do patamar de países desenvolvidos. Essas diferenças são maiores para softwares focalizados para questôes educacionais, mas convém destacar que o país mais bem equipado nesse sentido são os Estados Unidos, que nem por isso se destacam nos resultados do Pisa.

Em suma, apesar de o Pisa não poder medir a qualidade do aprendizado dos alunos brasileiros, por ser amostral e não abranger toda a educação básica, essa avaliação oferece elementos relevantes que decorrem de comparaçóes com outros países e que não se restringem ao desempenho nos exames, mas também dizem respeito às condiçóes de sociabilidade nas escolas, relacionamento entre alunos e professores, além de serem mencionados fatores extrínsecos à escola. Existem resultados que se destacam no Brasil, como a elevada incidência de ausências nas escolas, problemas de desrespeito aos professores e falta de assiduidade e preparo deles. Outros resultados parecem ser típicos de países não desenvolvidos, sendo o caso mais emblemático o patamar de desempenho ou, segundo os próprios alunos, do consumo de substâncias ilegais, ressaltando-se que o Brasil não apresenta resultados singulares nesses aspectos. Por fim, existem resultados em que as diferenças entre o Brasil e os países de renda mais elevada são pouco relevantes, como nas condiçóes de estudo em casa. Esse tipo de análise revela quais seriam as questóes que deveriam ser objeto da formulação de políticas públicas, ou seja, questôes incontornáveis para se garantir trajetória alentadora para a educação, que possa gerar desenvolvimento e mais equidade.

g) Meta 8

A meta 8 refere-se ao aumento da escolaridade da populaçấo jovem (18 a 29 anos), mediante o alcance de um mínimo de 12 anos de estudo para alguns segmentos deste universo populacional: residentes em áreas rurais e na região brasileira com menor escolaridade (Nordeste), bem como entre os jovens do primeiro quartil de renda. Além disso, estabelece a equiparação da escolaridade entre negros e não negros. 
Em termos médios, os jovens brasileiros dessa faixa etária ainda não atingiram 12 anos de estudos, que equivaleriam à conclusão do ensino fundamental de nove anos e do ensino médio. Em 2015, foi atingido o patamar de 10 anos de estudo, conforme mostra o gráfico 11 .

GRÁFICO 11

Escolaridade média (em anos de estudo) da população de 18 a 29 anos - Brasil (2005-2015)

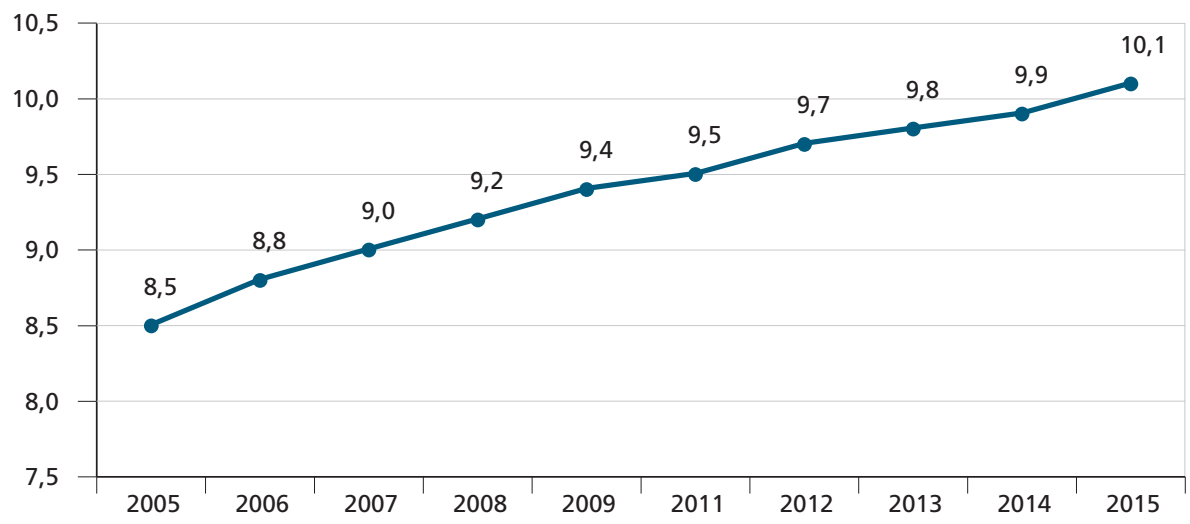

Fonte: Pnad/IBGE.

Elaboração: Disoc/lpea.

Pode-se constatar que houve aumento de 1,6 ano de estudo no período de dez anos. Portanto, incremento médio anual de apenas 0,16 ano de estudo. Mantido este ritmo de crescimento, ao final do PNE 2014-2024 poder-se-ia atingir um índice em torno de 11,5 anos de estudo. Em que pese não estar distante do mínimo de 12 anos estabelecido para os segmentos populacionais e territórios mais vulneráveis, deve-se ter em conta as desigualdades encobertas por esse índice médio.

A maior delas refere-se à renda (Indicador $8 \mathrm{C}$ ). Tendo-se como parâmetros os dois quartis de renda extremos, observa-se que, apesar de ter havido significativa redução das desigualdades sob esse enfoque, ainda há muito a avançar para que os jovens do $1^{\circ}$ quartil de renda consigam atingir os 12 anos de estudos até 2024 . Mesmo que o aumento verificado ao longo da última década (2,2 anos de estudo) fosse replicado no período restante da vigência do PNE 2014-2024, não seria insuficiente para o alcance da referida meta. 
GRÁFICO 12

Escolaridade média (em anos de estudo) da população de 18 a 29 anos, por quartis de renda domiciliar per capita selecionados - Brasil (2005-2015)

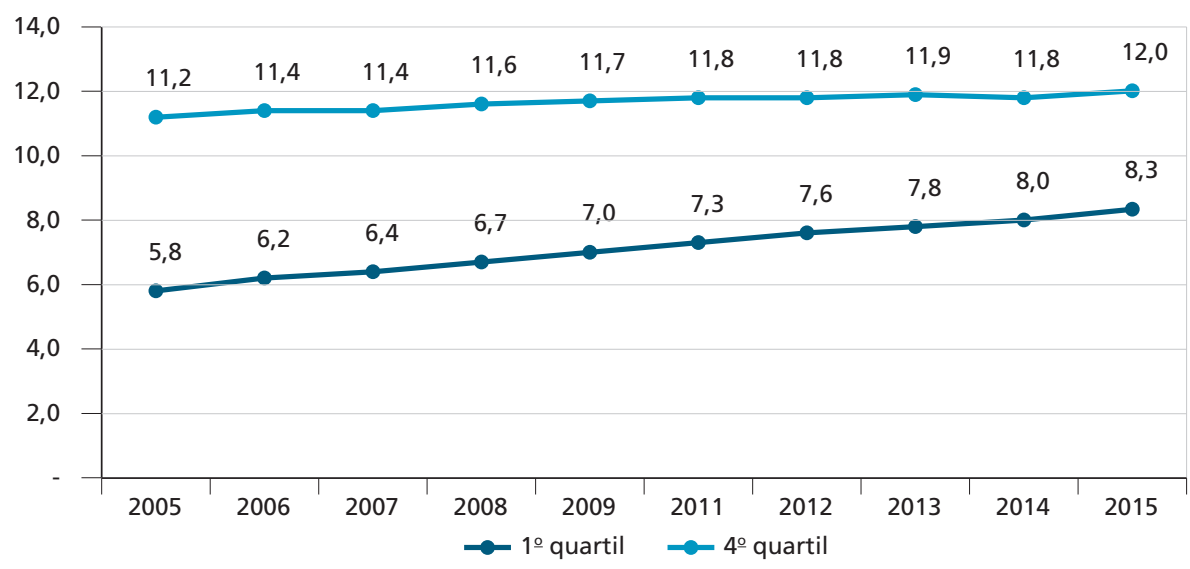

Fonte: Pnad/IBGE.

Elaboração: Disoc/lpea.

O gráfico 12 mostra que, apesar de ter sido reduzida a desigualdade entre os jovens pertencentes a esses dois estratos de renda ao longo do período 2005-2015, os que pertenciam ao $1^{\circ}$ quartil apresentavam desvantagem de 3,7 anos de estudo, a qual dificilmente deverá ser eliminada até 2024 , tendo em vista a evolução desse indicador ao longo desse período.

No que se refere à localização do domicílio (rural/urbano), verifica-se certa similaridade com as desigualdades sob a variável renda. É possível que tal semelhança esteja relacionada com as diferenças existentes entre rendimentos nas áreas urbanas e rurais, mas também às dificuldades de acesso à escola e à menor demanda por mão de obra escolarizada.

Em que pese ter havido redução da desigualdade no nível de escolaridade de jovens residentes no campo e nas cidades, a desvantagem dos primeiros em 2015 chegava a 2 anos de estudo, conforme o gráfico 13. 
GRÁFICO 13

Escolaridade média (em anos de estudo) da população de 18 a 29 anos residente em área rural - Brasil (2005-2015)

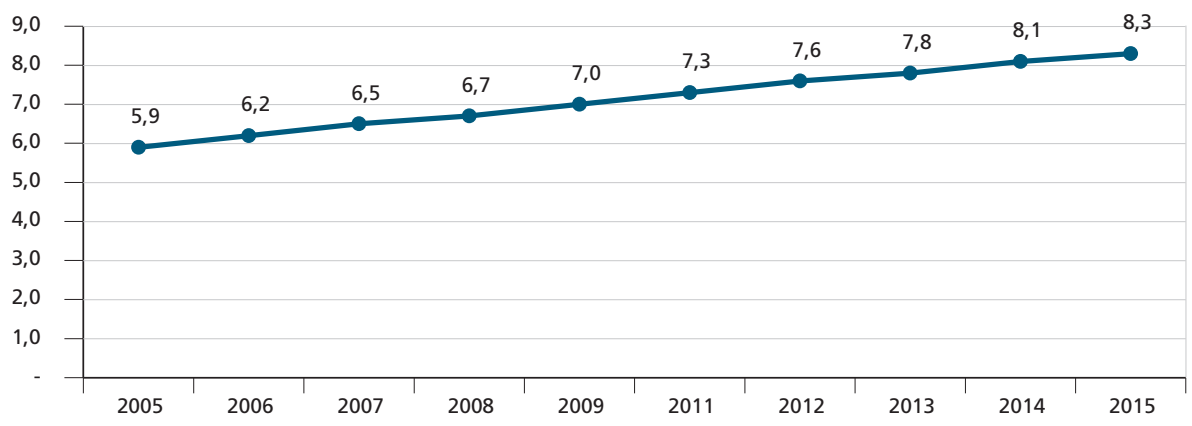

Fonte: Pnad/IBGE.

Elaboração: Disoc/lpea.

No caso de o ritmo de crescimento da última década ser mantido até o término da vigência do PNE 2014-2024, a estimativa é de que os jovens do campo possam atingir apenas 10,5 anos de estudo. Portanto, será necessário ampliar esforços para que essa meta possa ser alcançada.

A razão entre a escolaridade de negros e não negros corresponde ao indicador 8D. A evolução deste indicador guarda similaridade com aquela observada entre as macrorregiōes. A diferença de escolaridade entre esses dois grupos étnicos, observada em 2015, era a mesma que entre o Nordeste e o Sudeste (1,3 ano de estudo). Desse modo, o nível de escolaridade dos jovens negros correspondia a cerca de $88 \%$ da escolaridade média dos não negros (brancos e amarelos).

GRÁFICO 14

Razão de escolaridade em anos de estudo entre negros e não negros - Brasil (2005-2015)

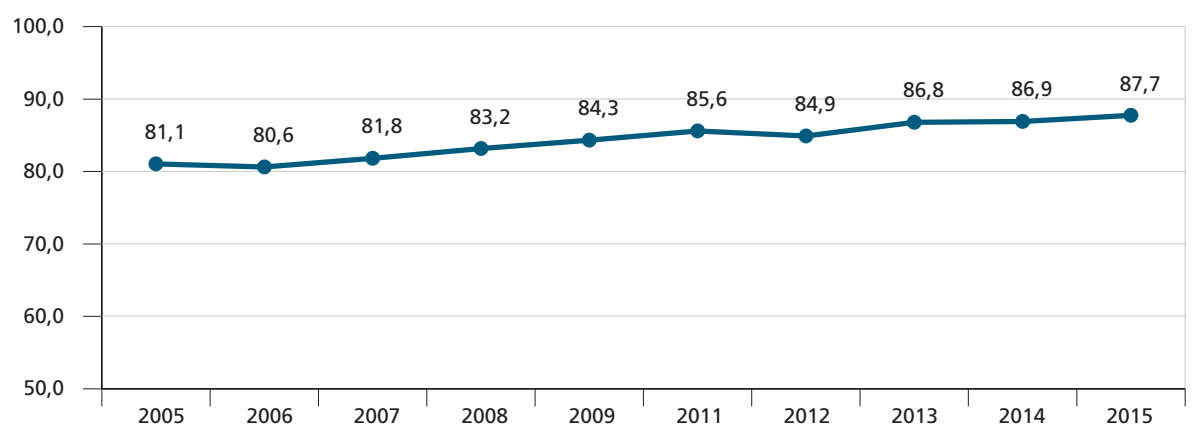

Fonte: Pnad/IBGE.

Elaboração: Disoc/lpea. 
Ao longo de uma década, foi reduzida a desigualdade entre ambos os grupos em 6,6 p.p. Portanto, mantida essa tendência de redução, ao final do PNE 2014-2024 poderia chegar-se à razão de 93,6\%. Assim, uma outra década seria necessária para ser eliminada a desigualdade na escolaridade média entre negros e não negros.

Por fim, quando se compara o nível de escolaridade entre as regióes com o maior e o menor índice - Sudeste e Nordeste -, verifica-se que a desigualdade entre ambas caiu consideravelmente. Se, em 2005, a diferença era de 2,2 anos de estudo, ao final do período sob análise havia sido reduzida para 1,3 ano de estudo. Com isso, a razão entre ambas se ampliou de $77 \%$ para $88 \%$.

GRÁFICO 15

Escolaridade média (em anos de estudo) da população de 18 a 29 anos, nas regiões Nordeste e Sudeste (2005-2015)

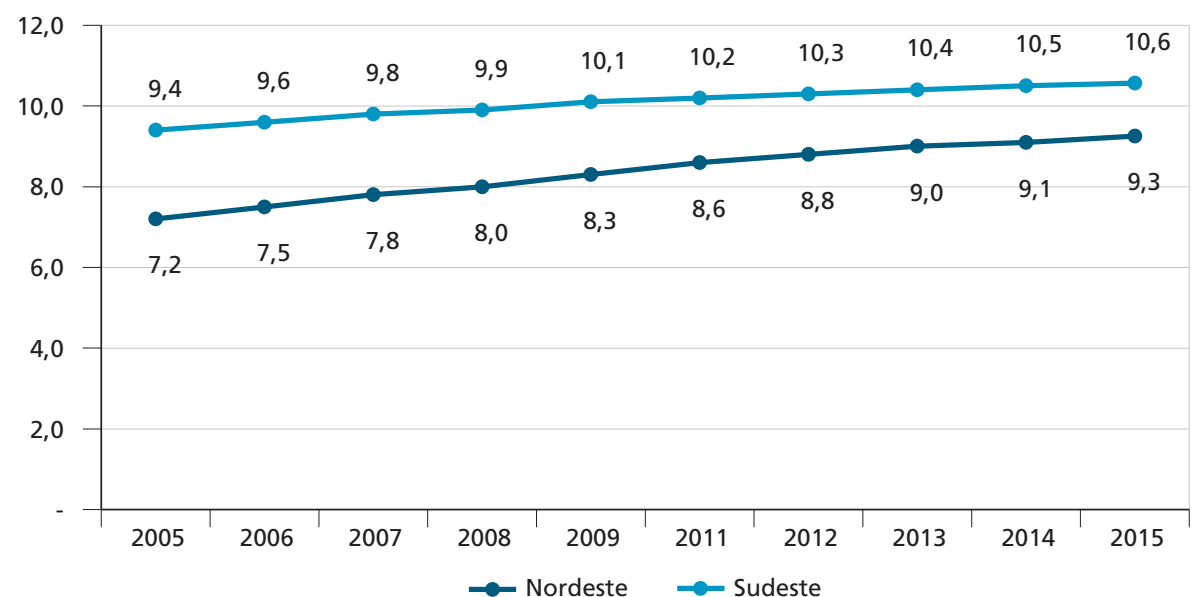

Fonte: Pnad/IBGE.

Elaboração: Disoc/lpea.

Outra forma de analisar as desigualdades existentes no nível de escolaridade dos jovens de 18 a 29 anos, segundo esses quatro recortes, pode ser mediante a substituição da categoria anos de estudo por deficit de escolaridade, a saber: $i$ ) sem instrução; $i$ i) sem ensino fundamental; e iii) sem ensino médio. Trata-se de uma abordagem que identifica de maneira mais precisa as carências na formação escolar da juventude brasileira, conforme é apresentado no gráfico 16 . 


\section{GRÁFICO 16}

Distribuição percentual da população de 18 a 29 anos segundo níveis de instrução e categorias selecionadas - Brasil (2015)

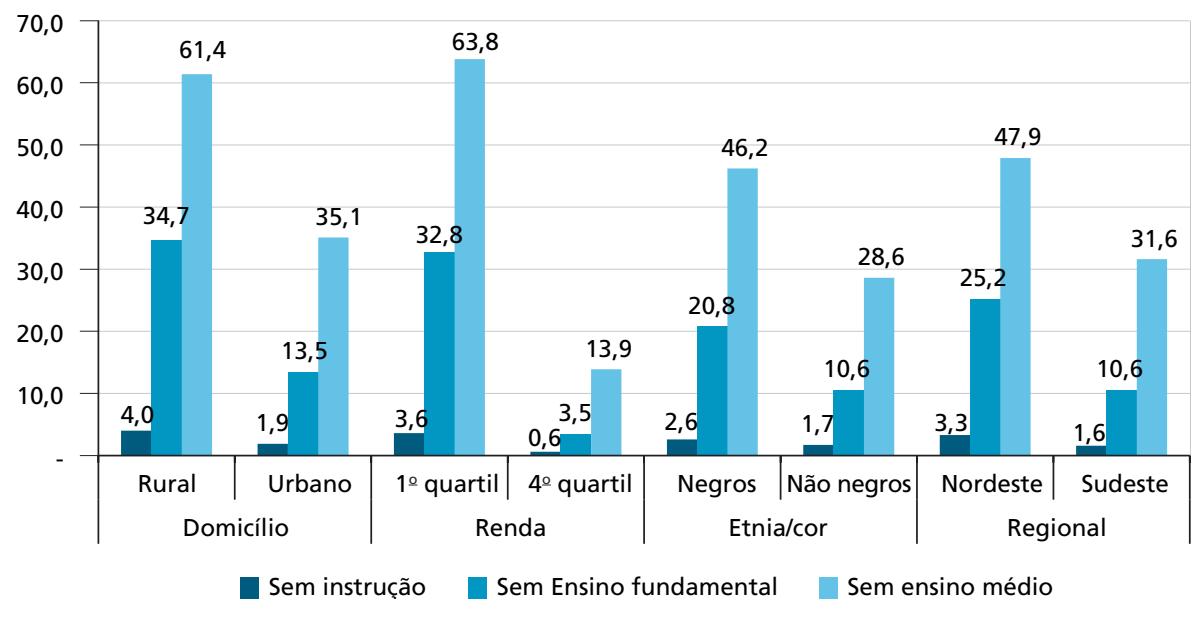

Fonte: Pnad/IBGE.

Elaboração: Disoc/lpea.

Conforme se observa no gráfico 16, os maiores deficit em termos de escolaridade são encontrados entre os jovens do $1^{\circ}$ quartil de renda e entre os residentes em áreas rurais. Em ambos os casos, mais de $60 \%$ não concluíram o ensino médio, assim como mais de 30\% sequer concluíram o ensino fundamental. Com relaçáo a este nível de ensino, chama atenção que a desigualdade entre os dois quartis de renda é de quase dez vezes.

Por sua vez, os deficit de escolaridade de negros guardam semelhanças com os da regiấo Nordeste, enquanto os de não negros são similares ao da região Sudeste.

h) Meta 9

A erradicação do analfabetismo constitui um desafio de longa data para a sociedade brasileira. No mínimo, desde o Movimento Brasileiro de Alfabetização (Mobral), instituído em 1967. Desde então, as expectativas e metas de programas dessa natureza têm sido muito ambiciosas, mas as iniciativas e ações têm se revelado limitadas.

De acordo com o PNE 2014-2024, a taxa de alfabetização da população de 15 anos ou mais deveria atingir 93,5\% em 2015, e a erradicação do analfabetismo deveria ocorrer até o final da vigência do plano. Porém, quando se observa a evolução desse indicador ao longo da última década, verifica-se que o ritmo de crescimento tem sido insuficiente para o alcance de meta tâo ousada. 
O outro indicador que compóe essa meta é o que se refere ao analfabetismo funcional. Neste caso, o Inep/MEC atribuiu o mínimo de 5 anos de estudo, equivalentes à primeira etapa do ensino fundamental, abaixo do qual estariam inseridos os analfabetos funcionais.

De acordo com o que estabelece o art. $4^{\circ}$ da Lei que instituiu o PNE 2014-2024, os indicadores que se utilizam da Pnad deverão considerar 2012 como ano base. Assim sendo, a taxa de analfabetismo funcional correspondia, nesse ano, a $18,3 \%$ da população de 15 anos ou mais, de modo que deverá ser reduzida à metade, ao término da vigência do plano.

Para se erradicar o analfabetismo até 2024, será necessário triplicar o ritmo de queda desse indicador, tendo-se por referência sua evolução no período 2005-2015. Em sentido contrário ao que essa aceleração demandaria, verifica-se que a execução financeira das duas açôes do MEC voltadas à alfabetização de jovens e adultos sofreu queda de $78 \%$ em 2015, na comparação com o ano anterior.

Considerando-se que os municípios, tidos como os entes mais frágeis da Federação, respondem majoritariamente pela oferta dessa modalidade de ensino, e que o apoio supletivo concedido pelo MEC foi drasticamente reduzido em 2015, diminuem as possibilidades de ampliação da oferta de vagas para a alfabetização de jovens e adultos.

A incidência do analfabetismo entre jovens e adultos está intimamente associada às condiçóes socioeconômicas, mas também resulta de fatores culturais e históricos. Ainda hoje, são profundas as diferenças entre as macrorregiões brasileiras, assim como entre os meios urbano e rural e entre estratos de renda opostos.

Sob a ótica regional, que abrange os demais fatores, em especial uma maior proporção de residentes em áreas rurais e de pessoas com baixa renda, verifica-se que, em 2015, a região Nordeste estava cerca de 12 p.p. atrás da região Sul. Diferença semelhante à existente entre um país africano (Gabão) e um europeu (Portugal). ${ }^{6}$ Portanto, no que concerne ao analfabetismo no Brasil, persiste a metáfora da "Belíndia", uma vez que três das cinco macrorregiôes brasileiras tinham taxa de analfabetismo igual ou inferior à de Portugal, mas uma delas aproximava-se da registrada pelo país africano supracitado. 
GRÁFICO 17

Taxa de alfabetização da população de 15 anos ou mais, nas regiões Nordeste e Sul (2005-2015)

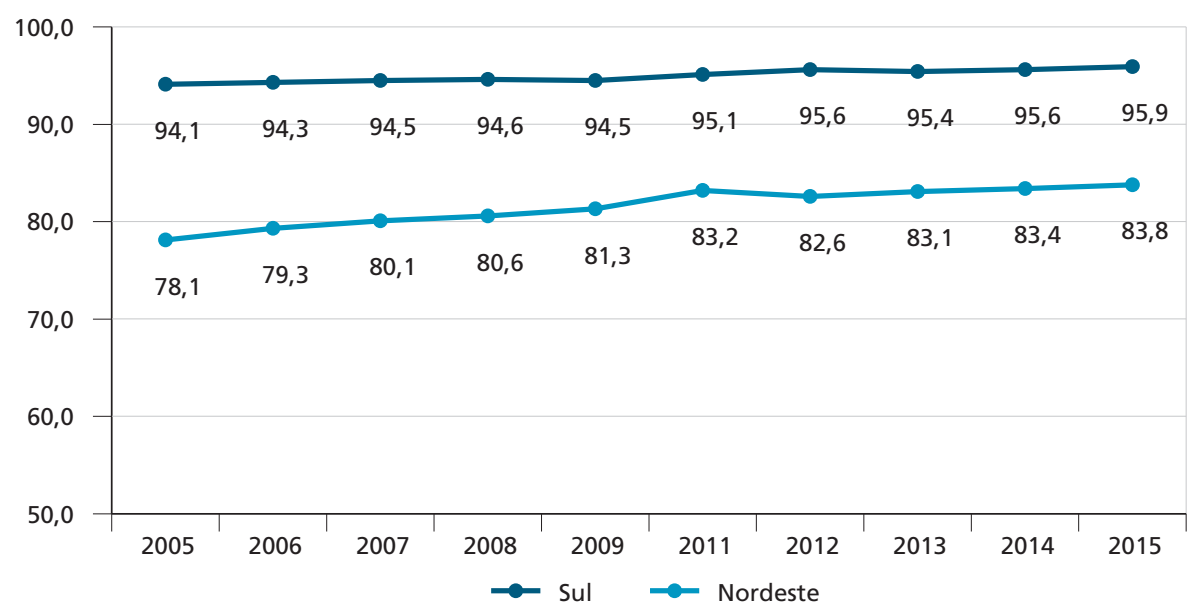

Fonte: Pnad/IBGE.

Elaboração: Disoc/lpea.

A partir dos dados contidos no gráfico 17, conclui-se que houve ampliação da razão entre as macrorregióes que tinham a menor e a maior taxa de alfabetização, de $83 \%$ em 2005, para $87 \%$ em 2015. Mesmo tendo havido redução da desigualdade que separava essas regiôes, esta continua sendo uma das maiores desigualdades educacionais existentes no país.

Tomando-se a renda, em separado, verifica-se que a taxa de alfabetização dos integrantes do quartil mais pobre era de $87,8 \%$, enquanto entre aqueles que se situavam no quartil mais rico atingia 98,1\%. Portanto, era de cerca de 10 p.p. a diferença entre esses estratos socioeconômicos.

A desigualdade relativa à localização do domicílio (rural/urbana) mostrava-se ainda mais acentuada, na medida em que atingia cerca de 14 p.p. Deve-se ressaltar que a reduçáo das desigualdades entre ambas as áreas deu-se em ritmo menos acelerado que, por exemplo, entre as macrorregióes Nordeste e Sul e entre os quartis de renda extremos.

Quando esses fatores estáo associados, amplia-se ainda mais a incidência do analfabetismo. Tal é o caso da população nordestina residente na área rural, de etnia negra e pertencente ao $1^{\circ}$ quartil de renda, cuja taxa situava-se em torno de $25 \%$, ou seja, mais do que o triplo da média nacional.

O segundo indicador que integra a meta 9 é a proporção de analfabetos funcionais na faixa etária de 15 anos ou mais. A definição operacional (mensurável) 
do analfabetismo funcional equivalia a menos de 4 anos de estudo, que correspondiam ao antigo ensino primário e, posteriormente, à primeira etapa do ensino fundamental. Mas, em virtude da ampliação de sua duração, de oito para nove anos, ocorrida em 2006, com ingresso do aluno a partir dos 6 anos de idade, a primeira etapa do ensino fundamental passou a denominar-se "anos iniciais", com duração de cinco anos.

No intuito de harmonizar as referidas fases iniciais do ensino fundamental, o IBGE estabeleceu que "na contagem dos anos de estudo para o ensino fundamental com duração de nove anos, a primeira série concluída com aprovação foi enquadrada em menos de 1 ano de estudo, a segunda série, em 1 ano de estudo, e assim, sucessivamente, até a nona série, classificada em 8 anos de estudo" (IBGE, 2015).

Além de abranger todos os que não haviam completado 4 anos de estudo, considerou-se também como analfabeto funcional o indivíduo que tenha atingido ou superado esse patamar de escolaridade, mas que se declarou analfabeto. Sob esta condição, a Pnad 2015 detectou a existência de 59,5 mil pessoas, ou seja, apenas $0,2 \%$ do universo de analfabetos funcionais. O gráfico 18 mostra a evolução desse indicador no período 2005-2015.

GRÁFICO 18

Taxa de analfabetismo funcional da população de 15 anos ou mais - Brasil

(2005-2015)

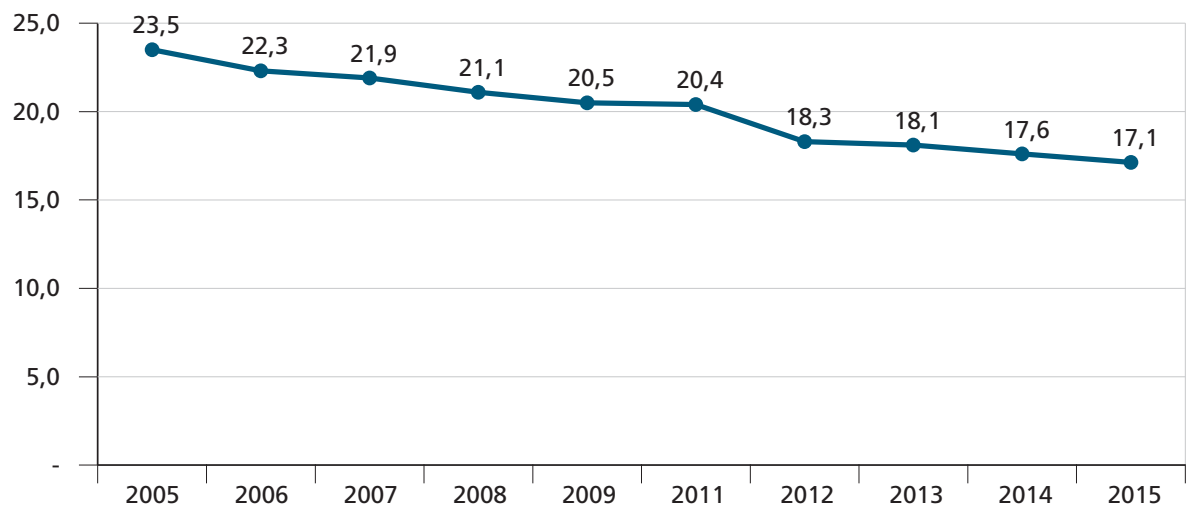

Fonte: Pnad/IBGE.

Elaboração: Disoc/lpea.

A taxa registrada em 2015 é cerca de 8 p.p. maior que a meta de 9,2\%, a ser alcançada ao final do PNE. Portanto, aqui também será necessário acelerar o ritmo de queda observado no período 2005-2015, que foi de pouco mais de 0,6 p.p. ao ano. 
A concentração do analfabetismo funcional assemelha-se à do analfabetismo convencional. A região Nordeste, a área rural, o $1^{\circ}$ quartil de renda e pessoas na faixa etária de 40 anos ou mais apresentam taxas muito acima da média nacional, conforme é mostrado no gráfico 19.

GRÁFICO 19

Taxa de analfabetismo funcional, segundo categorias selecionadas - Brasil (2015)

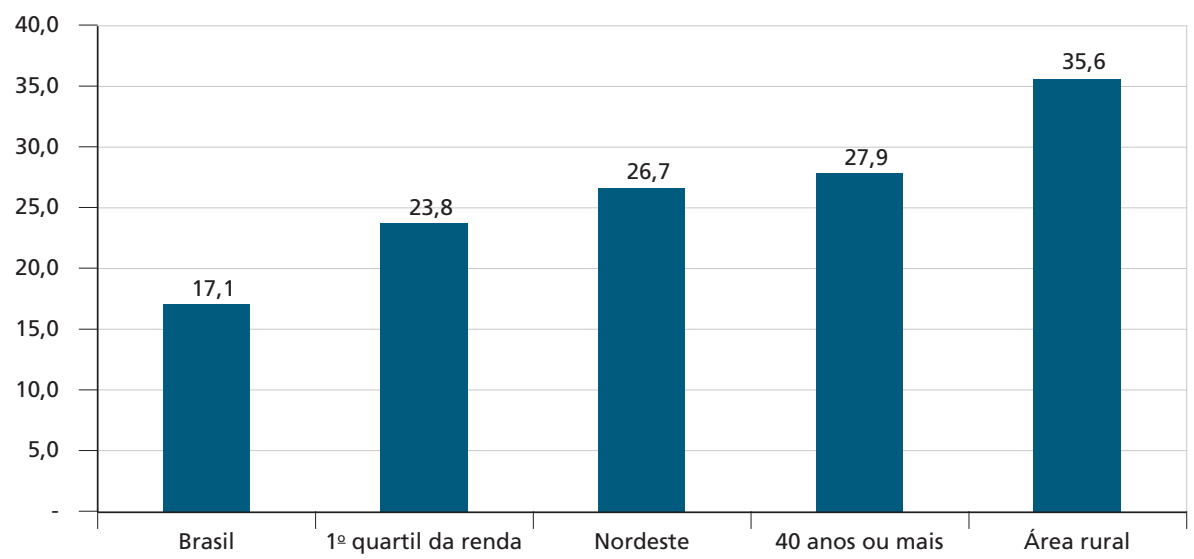

Fonte: Pnad/IBGE.

Elaboração: Disoc/lpea.

No caso dos residentes em áreas rurais, o índice médio é mais que o dobro da média nacional, mas também são muito elevadas as proporçóes de analfabetos funcionais entre adultos e idosos, na população residente no Nordeste e entre os mais pobres. Em grande medida, explica-se a elevada proporção de analfabetos funcionais nesta região devido à elevada proporção de pobres e residentes no campo.

\subsection{EDUCAÇÃO PROFISSIONAL E TECNOLÓGICA}

A educação profissional e tecnológica (EPT) é contemplada no PNE 2014-2024 com duas metas específicas, que visam à ampliação da oferta e do consequente acesso a este nível de ensino. A meta 10 trata da ampliação das matrículas na educação de jovens e adultos integrada à educação profissional à proporção de $25 \%$ do total, enquanto a meta 11 estabelece que sejam triplicadas as matrículas na educação profissional de nível médio, devendo ocorrer pelo menos a metade desse aumento nas redes públicas de ensino. Portanto, são metas que pressupóem o aumento significativo dos investimentos públicos em infraestrutura e manutenção do ensino. 


\section{i) Meta 10}

A meta 10 é composta de apenas um indicador: percentual de matrículas da educação de jovens e adultos na forma integrada à educação profissional. Com base na evolução deste indicador e, principalmente, no índice registrado em 2015, pode-se afirmar que a meta não será alcançada até o final da vigência do PNE. Conforme se observa no gráfico 20 , o índice de $3 \%$ está muito aquém da meta de $25 \%$ prevista para 2024, e o aumento no período 2008-2015 foi de apenas 2.6 p.p.

GRÁFICO 20

Percentual de matrículas da educação de jovens e adultos na forma integrada à educação profissional - Brasil (2008-2015)

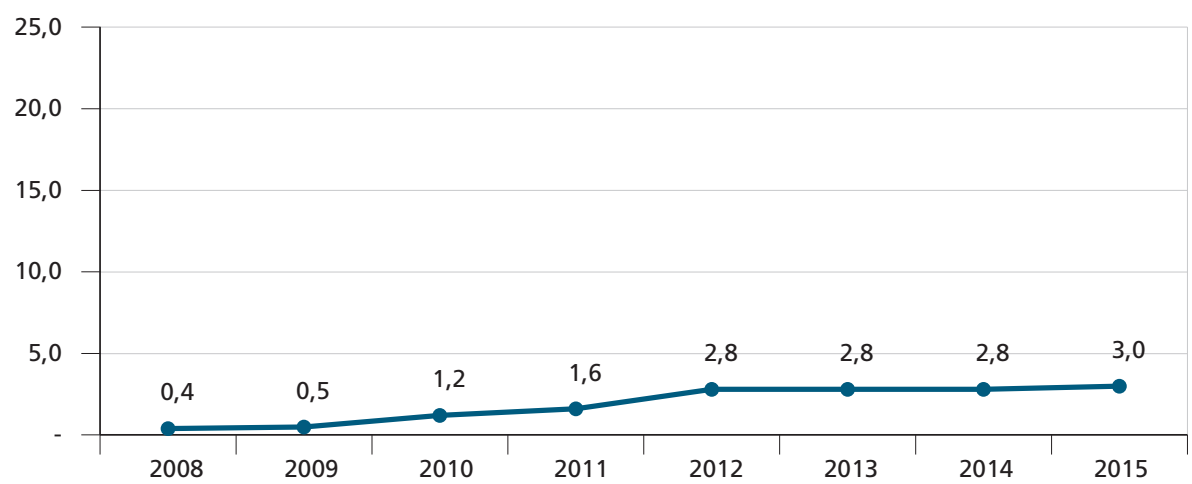

Fonte: Inep/MEC.

Elaboração: Disoc/lpea.

Além de tal meta implicar o aumento significativo de vagas ofertadas, ${ }^{7}$ o que demandaria investimentos que estão fora de cogitação neste contexto de recessão econômica, deve-se ter em conta que, via de regra, os estudantes matriculados em educação de jovens e adultos (EJA) não dispóem de tempo para uma formação em tempo integral. Por exemplo, de acordo com a Pnad 2015, entre os que frequentavam EJA do ensino médio, 59\% trabalhavam ou estavam afastados temporariamente do trabalho na semana de referência da pesquisa, o que leva a crer que uma jornada ampliada de estudos para essa parcela dos estudantes seria inviável.

Outros fatores poderiam limitar o acesso de estudantes de EJA na forma integrada à educação profissional, tais como a faixa etária, o gênero e a situação conjugal. De acordo com a Pnad 2015, entre os que frequentavam EJA no ensino médio em 2015, havia 52\% na faixa etária de 30 anos ou mais e $54 \%$ de mulheres, sendo que $59 \%$ destas tinham cônjuge ou companheiro. Entre aqueles estudantes de EJA que não trabalhavam, predominavam as mulheres (62\%), sendo que a maioria destas (59\%) tinham cônjuge ou companheiro. 
Portanto, são fatores que podem dificultar a ampliação da jornada escolar desses estudantes ou, então, indicar o desinteresse desses grupos em agregar formação profissional em nível médio.

\section{j) Meta 11}

A meta 11 é composta de dois indicadores, a saber: $i$ ) número absoluto de matrículas em EPT de nível médio; e ii) percentual das matrículas em EPT de nível médio na rede pública. No primeiro caso, a meta é triplicar o número de matrículas existentes em 2013 (cerca de 1,6 milhão). Portanto, para cumprir esta meta, será necessário superar o patamar de 4,8 milhóes de matrículas em 2024. O segundo indicador é o que atribui às redes públicas a proporção de ao menos $50 \%$ desse aumento. Ou seja, caberá a elas o incremento de cerca de 1,6 milhão de matrículas.

Trata-se de desafios bastante ousados, quando se tem em conta o vulto dos investimentos que se fazem necessários para a ampliação da oferta de vagas nessa proporção. Além disso, a recessão econômica e a perspectiva de baixo crescimento para os próximos anos não geram estímulos à qualificação profissional de médio e longo prazo. Portanto, se ambas as premissas forem plausíveis, reduzem-se as chances de atingimento das referidas metas.

No que se refere às matrículas totais, seria necessário incremento médio anual de cerca de 290 mil matrículas, no período 2013-2024. Cabe mencionar que esse montante foi praticamente atingido em 2014, quando se registrou aumento de 283 mil matrículas, na comparação com o ano anterior. Porém, no ano seguinte a situação se inverteu, momento em que se verificou a primeira reduçáo na série histórica iniciada em 2008, da ordem de 60 mil matrículas, conforme o gráfico 21 .

GRÁFICO 21

Matrículas em EPT de nível médio - Brasil (2008-2015)

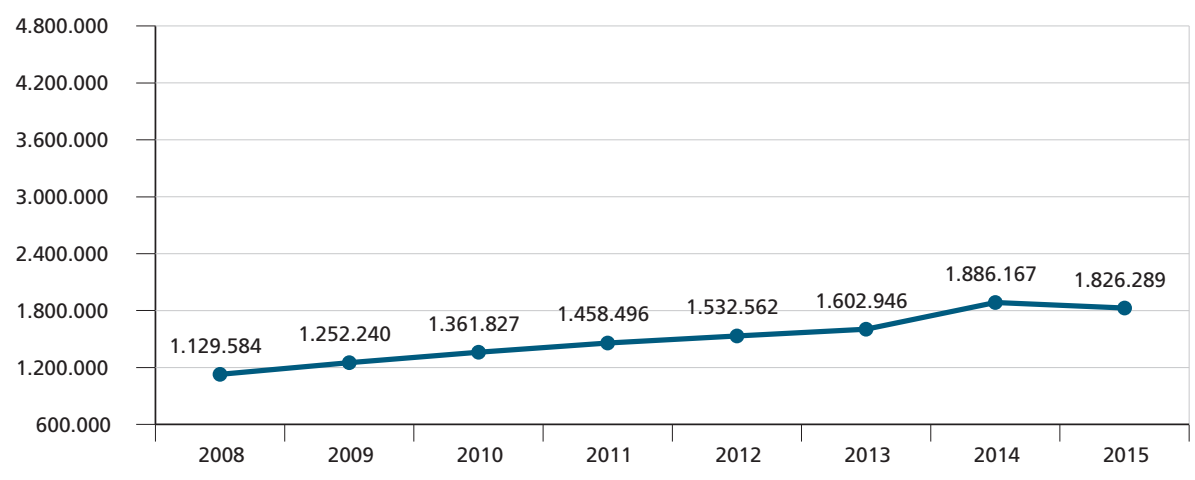


Um aspecto positivo a ser ressaltado é que as regiōes mais pobres do país tiveram crescimento mais acentuado das matrículas em EJA do ensino médio, no período sob análise. Enquanto no Sul e no Sudeste o aumento foi de 34\% e $39 \%$, respectivamente, nas demais regióes oscilou entre 108\% (Nordeste) e 192\% (Centro-Oeste).

No que tange ao segundo indicador - a participação das redes públicas no total de matrículas -, observa-se que, no período 2008-2011, houve uma estabilização em torno de $59 \%$ do total. A partir de 2012, reduz-se a participação da esfera pública, até se atingir o menor patamar em 2014. Porém, em 2015 amplia-se novamente essa proporção, mas ainda abaixo do patamar do início da série histórica, conforme é mostrado no gráfico 22 .

GRÁFICO 22

Percentual das matrículas em EPT de nível médio nas redes públicas - Brasil (2008-2015)

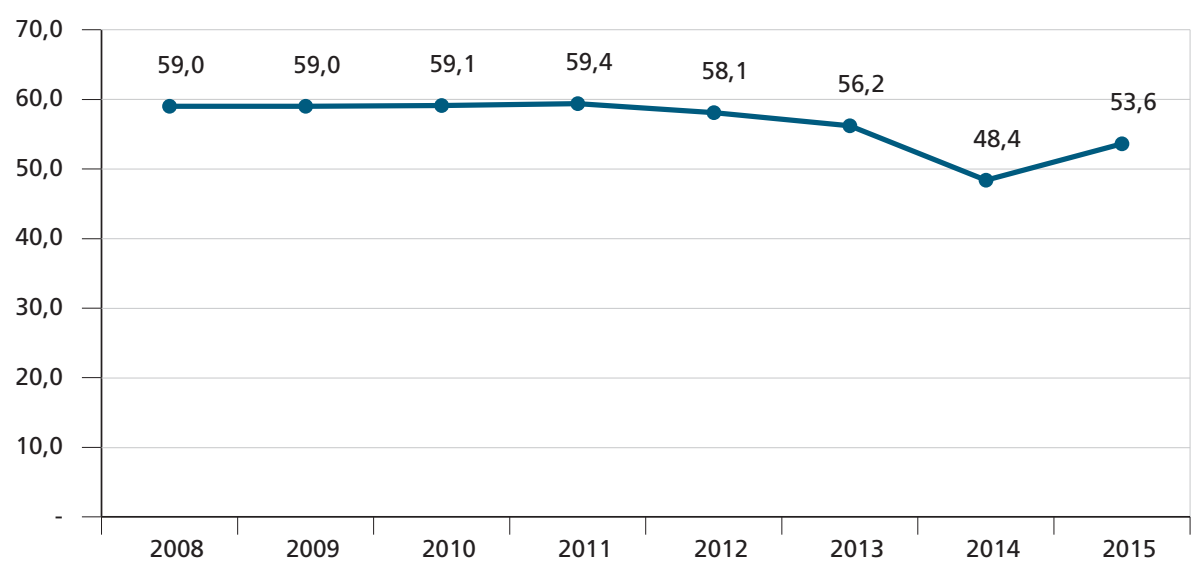

A retomada da liderança das redes públicas em 2015 foi possível em razão do aumento de $7 \%$ em suas matrículas e da redução de cerca de $13 \%$ ocorrida no setor privado.

\subsection{EDUCAÇÃO SUPERIOR}

As metas do PNE 2014-2024, no âmbito da educação superior, tratam da ampliação do acesso (meta 12), qualificação do corpo docente (meta 13) e titulação de pessoal em nível de pós-graduação stricto sensu (meta 14).

O principal desafio da educação superior no Brasil pode ser sintetizado pela meta 12 , haja vista que a ampliação das taxas de frequência bruta e líquida depende de fatores que vão além da oferta de vagas neste nível de ensino. 
No caso da meta 13, que estabelece titulação mínima de docentes em exercício na educação superior ( $35 \%$ de doutores e $75 \%$ com no mínimo mestrado), verifica-se que ambos os índices foram superados em 2015. De fato, o primeiro deles já havia sido atingido em 2014, conforme consta na edição anterior deste periódico. No entanto, há desigualdades significativas entre redes de ensino e macrorregiôes brasileiras.

Em relação à meta 14, que trata do número de titulados com mestrado e doutorado, observa-se, pela evolução nos últimos anos, que o alcance é factível alcançá-la. Apenas em 2015, houve aumento de 9,3\% no número de doutores e de $6,6 \%$ no de mestres.

\subsubsection{Sobre a ampliação do acesso à educação superior}

Para o alcance da meta 12, serão necessários esforços de maior vulto e intervençóes mais complexas, tendo em vista o lapso que separa a realidade atual da situação desejada. A complexidade da problemática que envolve o alcance dessa meta vai além da oferta de vagas, ou seja, da capacidade de atendimento atual.

Em primeiro lugar, a oferta desse nível de ensino é predominantemente privada, o que pressupóe a disponibilidade de recursos financeiros para aqueles que não tenham acesso ao Fies ou ao Programa Universidade para Todos (ProUni). Em $2015,72,5 \%$ das matrículas, $77,4 \%$ dos ingressantes e $85,9 \%$ das vagas ofertadas nos cursos de graduação presenciais estavam na esfera das instituiçôes de ensino superior (IES) privadas.

Ao longo da última década, o crescimento das matrículas na rede privada não teve o mesmo dinamismo verificado no período 1995-2005, em que pese o aumento expressivo na concessão de bolsas do ProUni e de contratos de financiamentos junto ao Fies. Se, no período 1995-2005, o crescimento foi de 208\%, na década seguinte limitou-se a $47 \%$.

Por sua vez, as IES públicas registraram crescimento de $53 \%$ no período 2005-2015, na modalidade presencial. Entre estas, destacam-se as instituições federais de ensino superior (Ifes), que ampliaram as matrículas nesse período em cerca de $96 \%$. Cabe ressaltar que participação das redes públicas nas matrículas em cursos a distância é residual (9\% do total, em 2015).

Quando se consideram todas as redes e modalidades de ensino (presencial e a distância), verifica-se que o crescimento na última década foi de $76 \%$, também bastante inferior aos 160\% registrados no período 1995-2005. A variação anual do número de matrículas é apresentada no gráfico 23, dos cursos presenciais e do somatório destes com os cursos a distância. 
GRÁFICO 23

Taxa de crescimento das matrículas em cursos de graduação nas IES privadas Brasil (1996-2015)

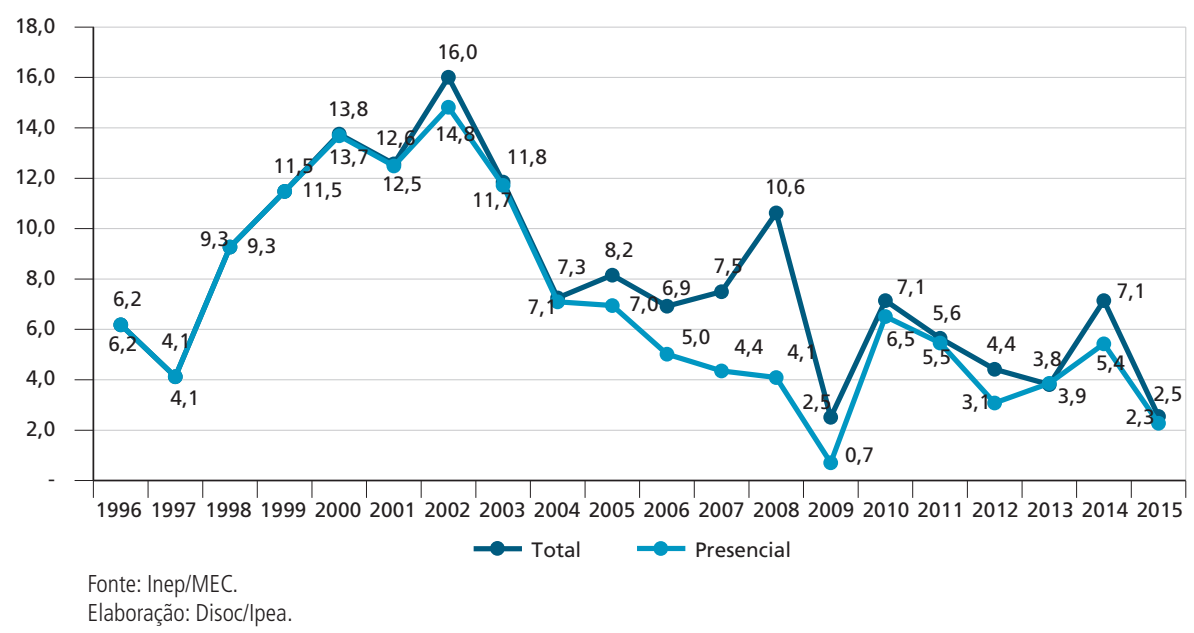

Os dados do Censo da Educação Superior 2015 evidenciam forte redução do número de ingressantes na educação superior no Brasil. O total de ingressantes caiu $6,6 \%$ em relação ao ano anterior, sendo que a queda no setor privado foi ainda mais acentuada (8,4\%). Quando se tomam apenas os estudantes que ingressaram por meio de processo seletivo, verifica-se que a redução chega a $10 \%$. Nas redes públicas, o número de ingressantes permaneceu praticamente inalterado, em que pese ter havido redução de $30 \%$ nas IES municipais. De modo distinto, as redes estaduais e a federal registraram aumento médio de cerca de $3 \%$.

Em grande medida, a redução do número de ingressantes no setor privado está associada às mudanças nas regras de contratação do Fies, introduzidas em 2015, assim como à diminuiçẫo na oferta de contratos. ${ }^{8}$ Desse modo, se no ano anterior haviam sido firmados cerca de 733 mil contratos novos, em 2015 chegou-se a pouco mais de 287 mil beneficiários. Portanto, cerca de 445 mil contratos a menos que em 2014.

Todavia, essa redução no número de contratos firmados corresponde a quase o triplo da redução do número de ingressantes nas IES privadas (157 mil). Por conseguinte, uma vez que o corte na oferta de contratos novos no Fies não foi acompanhado de redução semelhante do número de ingressantes, pode-se supor que uma parcela significativa de potenciais contratantes do Fies estava apta a ingressar na educação superior privada sem o aporte do financiamento estudantil, e que as regras de contratação do Fies, vigentes no período 2010-2014, suscitaram 
a ocorrência de um efeito crowding-out, uma vez que ofereciam financiamento com taxa de juros mais baixa que a rentabilidade do mercado financeiro, inclusive a da caderneta de poupança. Com isso, parcela significativa dos estudantes teria optado pelo contrato junto ao Fies ao longo desse período, mesmo dispondo de capacidade financeira para arcar com o pagamento das mensalidades escolares.

Outra evidência desse efeito crowding out é dada pela proporção de contratos ofertados que foram efetivamente firmados. Mesmo tendo sido reduzido de forma drástica o número de contratos ofertados em 2015, cerca de $8 \%$ do total não foram efetivados. Este fato pode estar associado a pelo menos dois fatores: desinteresse entre aqueles que poderiam tornar-se beneficiários do Fies e/ou insuficiência de demandantes elegíveis pelas novas regras.

Portanto, essa inflexão na expansão dos ingressos na educação superior ocorrida em 2015, com perspectivas de persistência em 2016, torna ainda mais improvável o alcance das metas estabelecidas no PNE 2014-2024, que já constituía uma tarefa hercúlea, caso fosse mantida a trajetória de crescimento ao longo dos anos que antecederam a aprovação desse plano.

\subsubsection{Principais programas e ações associados à meta 12}

Os principais programas governamentais de fomento à educação superior privada são o Fies e o ProUni. No primeiro caso, a expansão foi bastante significativa, especialmente no período 2010-2014, motivada pelas mudanças nas regras de concessão, conforme mencionado anteriormente e analisado na edição no 24 deste periódico. Por sua vez, o ProUni tem crescido como proporção das matrículas de alunos pagantes (uma bolsa para cada 9,5 alunos pagantes), o que implica limites objetivos na sua expansão.

GRÁFICO 24

Bolsas concedidas pelo ProUni e contratos novos do Fies - Brasil (2010-2015)

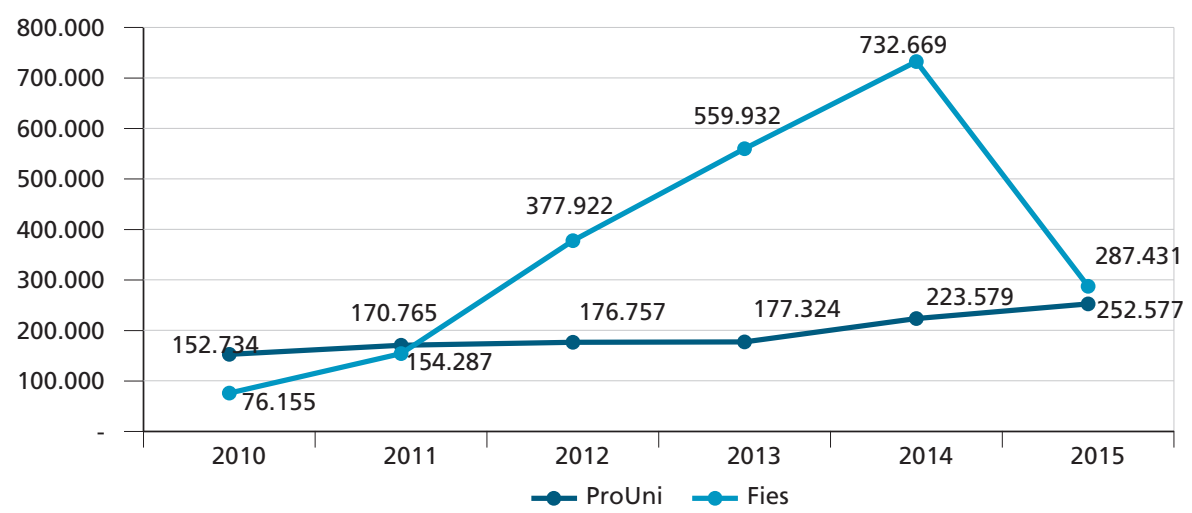

Fonte: Inep/MEC; SESu/MEC.

Elaboração: Disoc/lpea. 
Tal como pode ser observado no gráfico 24, o Fies teve crescimento excepcional no período 2010-2014, o que permitiu que fosse ampliada substancialmente a relação entre o número de beneficiários do Fies/ProUni e o de ingressantes na educação superior privada, apresentada no gráfico 25 .

GRÁFICO 25

Proporção de bolsas do ProUni e contratos do Fies em relação ao número de ingressantes na educação superior privada - Brasil (2010-2015)

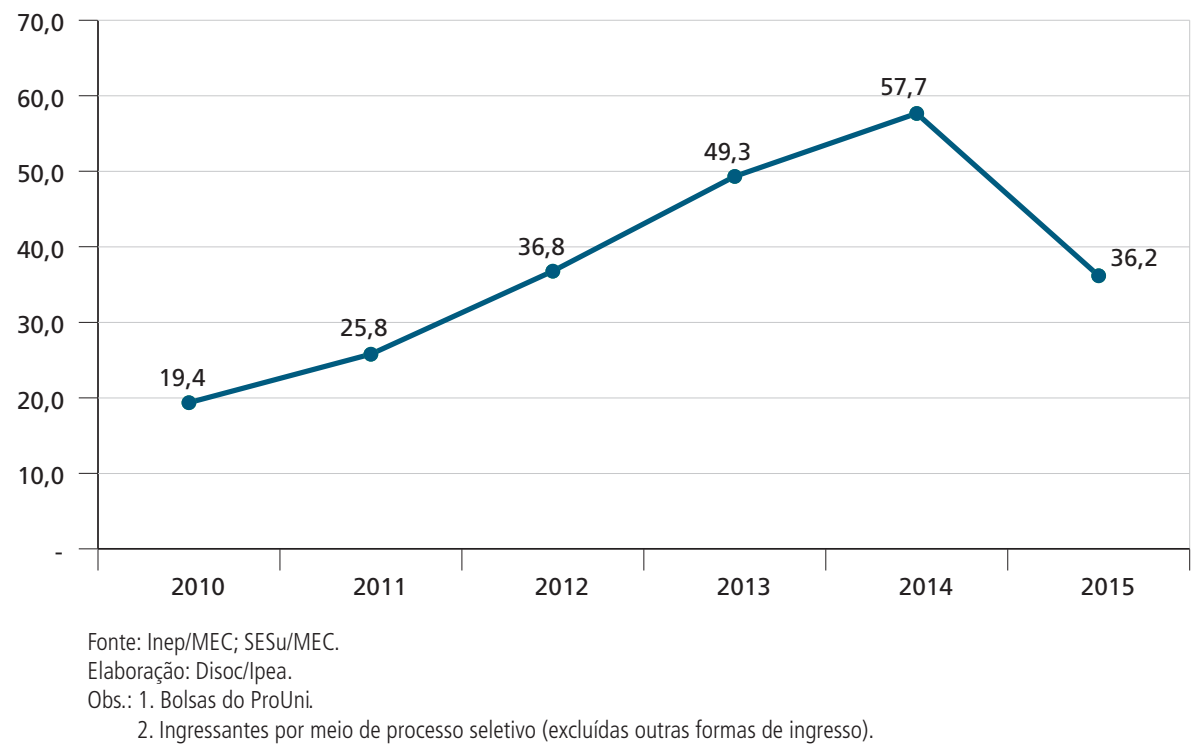

Se em 2010 o Fies respondia por 33\% dos beneficiários desses dois programas, em 2014 atingia a proporção de 77\%. Porém, no ano seguinte, sua participação havia recuado para $53 \%$, ficando o ProUni com os $47 \%$ restantes.

Um aspecto bastante positivo que merece ser destacado refere-se à distribuição dos contratos pelas cinco macrorregióes brasileiras. Sob esse enfoque, pode-se afirmar que as regióes mais pobres foram as mais favorecidas. No período de grande expansão do programa (2010-2014), o Norte, o Nordeste e o Centro-Oeste tiveram aumento de sua participaçáo no total de contratos firmados a cada ano, conforme pode ser observado no gráfico 26 . 
GRÁFICO 26

Distribuição percentual dos contratos firmados junto ao Fies, por macrorregião (2010 e 2014)

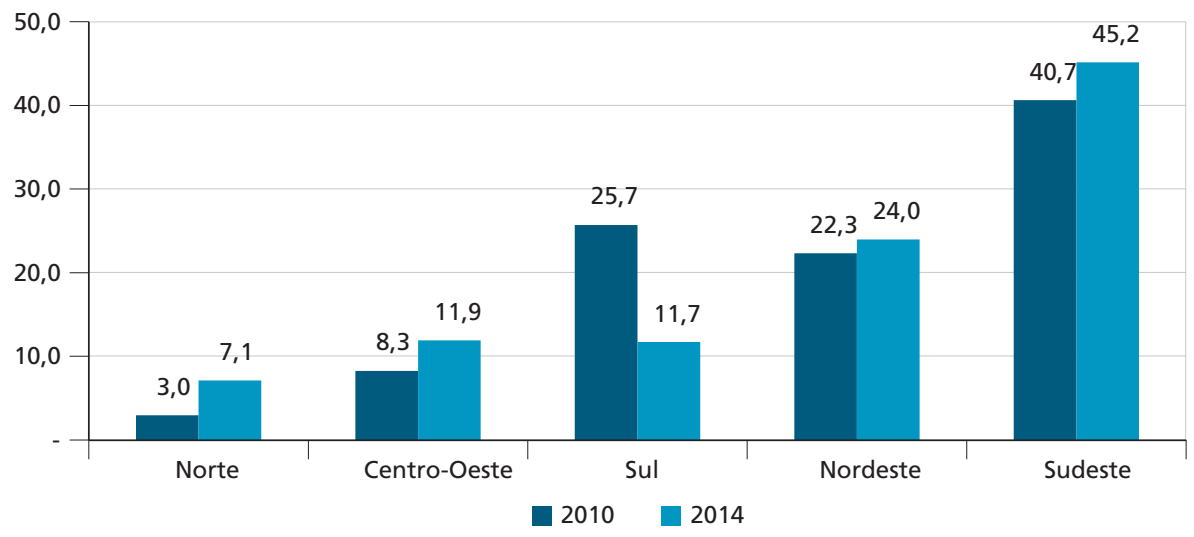

Fonte: FNDE/MEC.

Elaboração: Disoc/lpea.

Esse aumento da participação em quatro das cinco macrorregióes foi acompanhado de expressiva queda na região Sul. Para além dessas oscilaçóes identificadas, que podem ter sido causadas por fatores diversos, caberia verificar em que medida a apropriação dos contratos do Fies corresponde à proporção de vagas ofertadas pelas IES privadas em cada macrorregião.

Quando se tem por referência as vagas ofertadas, constata-se que, no período 2010-2014, houve aumento da participação apenas nas regióes Norte e Nordeste, o que seria algo esperado, haja vista que estas regióes ainda registram as menores taxas de acesso à educação superior, bem como as menores proporçóes de matrículas da rede privada, quando comparadas às demais regióes. Desse modo, calculou-se a razão entre a proporção de contratos do Fies e a de vagas ofertadas em cada macrorregiáo. O resultado é apresentado no gráfico 27.

O gráfico 27 evidencia elevado crescimento dos contratos do Fies como proporção das vagas ofertadas em todas as cinco macrorregióes. Entretanto, os maiores ganhos foram registrados junto às regióes mais pobres do país, fato este que contribui para a redução das desigualdades de acesso à educação superior sob esse recorte. 
GRÁFICO 27

Razão entre os contratos do Fies e as vagas ofertadas pelas IES privadas, por macrorregião (2010 e 2014)

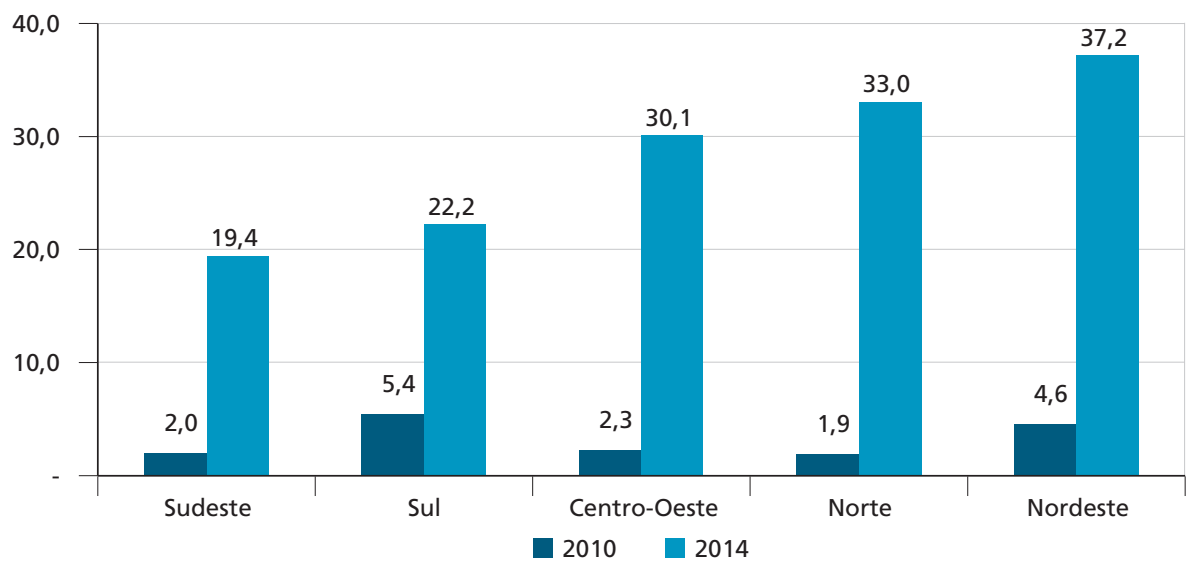

Fonte: FNDE/MEC; Inep/MEC.

Elaboração: Disoc/lpea.

Conforme se observa no gráfico 28 , mais de $93 \%$ dos beneficiários do Fies em 2016 tinham renda familiar per capita de até 1,5 salário mínimo (SM), enquanto no início da década representavam menos de $82 \%$ do total. Cabe ressaltar que o crescimento mais expressivo foi registrado entre aqueles com renda de até $1 \mathrm{SM}$, cuja participaçáo no total ampliou-se de 52\% para $71 \%$.

GRÁFICO 28

Distribuição dos beneficiários do Fies por faixas de renda familiar per capita selecionadas - Brasil (2010-2016)

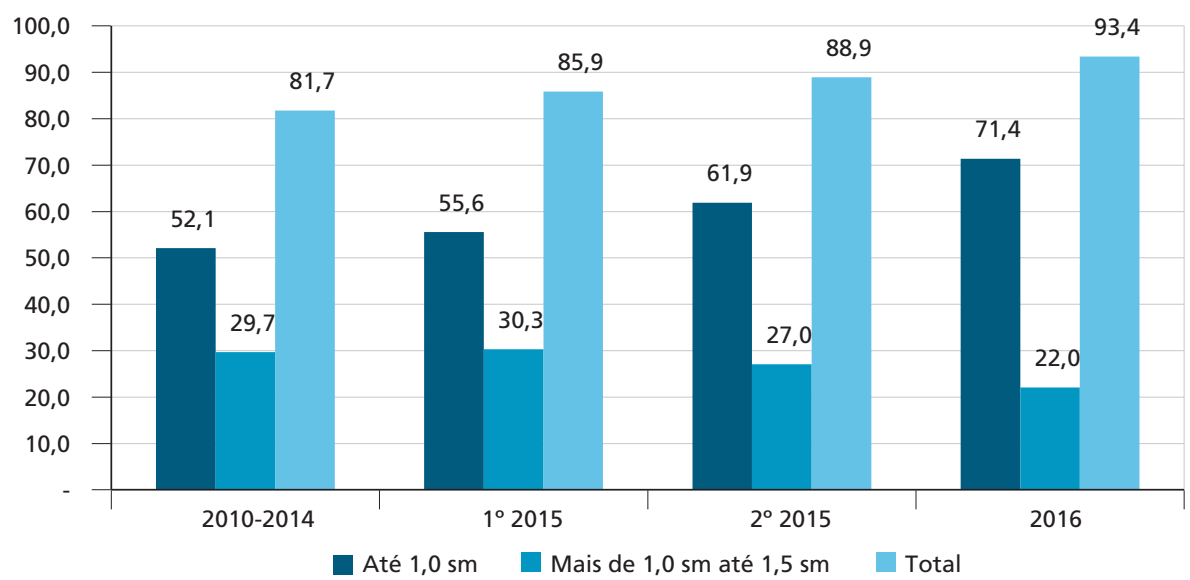

Fonte: FNDE/MEC.

Elaboração: Disoc/lpea. 
Esse aumento crescente da proporção de beneficiários do Fies a partir do $1^{\circ}$ semestre de 2015 deveu-se às mudanças nas regras do programa, que estabeleceram o teto de renda familiar per capita de 2,5 SMs, que, posteriormente, foi elevado para $3 \mathrm{SMs}$.

Se, por um lado, esse aumento na proporção de beneficiários com renda de até $1 \mathrm{SM}$ mostra que houve ampliação do atendimento àqueles que mais precisam, por outro, a persistência de proporção significativa de contratos não efetivados no biênio 2015-2016 pode estar relacionada à demanda insuficiente - por exemplo, pelo fato de ainda ser bastante baixa a proporção de pessoas desta faixa de renda que haviam concluído o ensino médio, tal como é mostrado no gráfico 29.

GRÁFICO 29

Percentual da população que havia concluído o ensino médio, por faixas etárias e de renda selecionadas - Brasil (2014)

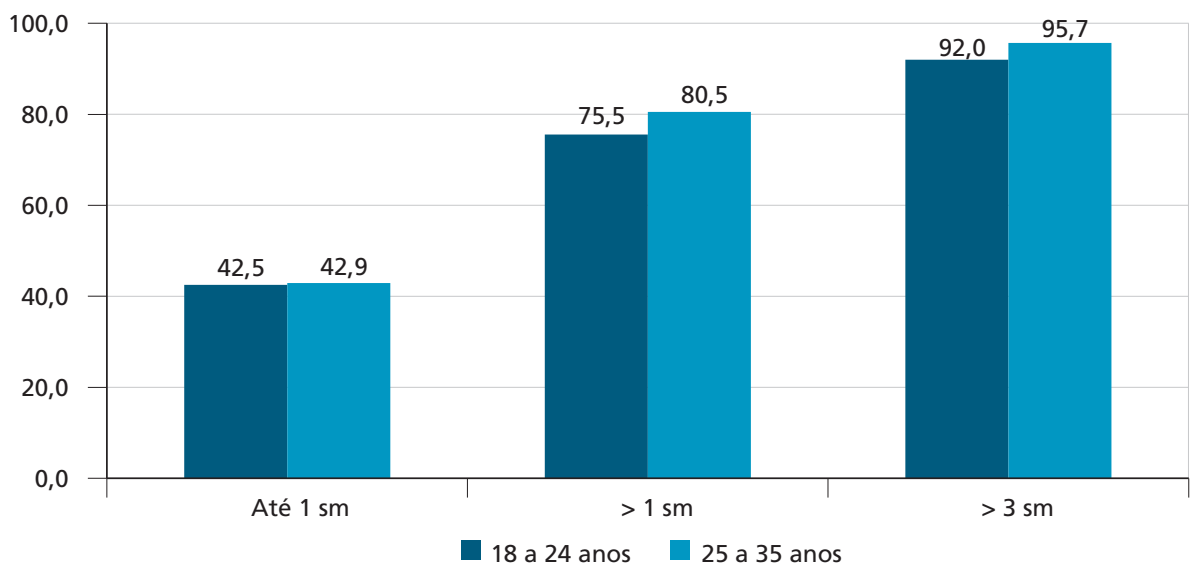

Fonte: Pnad/IBGE.

Elaboração: Disoc/lpea.

\subsubsection{Sobre a titulação do corpo docente}

A meta 13, que estabelece padrões mínimos de titulação nas instituições de educação superior, foi atingida ainda no primeiro ano de execuçáo do PNE 2014-2024. Isso não significa que a situação atual seja a ideal, mas, sim, que tal meta foi subestimada, uma vez que o nível de titulação à época da definiçẫo da meta já se encontrava muito próximo desta. Além disso, não foram definidos recortes regionais e, principalmente, por rede de ensino, que evidenciassem as desigualdades existentes.

De acordo com o Censo da Educação Superior 2015, a proporção de professores com doutorado havia atingido cerca de $40 \%$ do universo em exercício, o que corresponde a 5 pontos percentuais (p.p.) acima da meta a ser alcançada até 2024. Em relação aos docentes com titulação mínima de mestrado, foi atingida a proporção de $76 \%$, ou seja, 1 p.p. acima da meta estabelecida. 
No entanto, quando se desagregam os dados pelas cinco macrorregióes brasileiras, verifica-se que, no Centro-Oeste e no Norte, não foi atingida a meta de $75 \%$. O mesmo se aplica à meta de $35 \%$ de professores doutores, sendo que, neste caso, a meta também não foi alcançada na região Nordeste, conforme é apresentado no gráfico 30 .

GRÁFICO 30

Percentual de docentes por níveis de titulação selecionados, por macrorregião (2015)

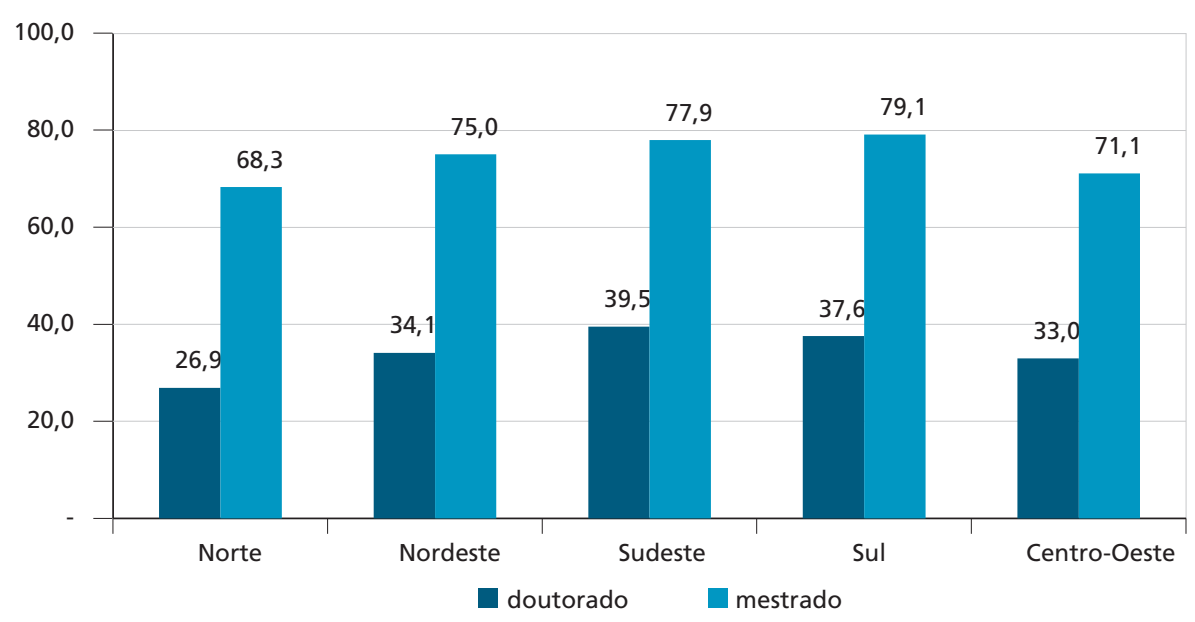

Fonte: Inep/MEC.

Elaboração: Disoc/lpea.

O gráfico 30 mostra que apenas a regiáo Norte se encontra um pouco mais distante da meta relativa aos doutores, com cerca e 8 p.p. abaixo dos $35 \%$. Porém, deve-se ter em conta que esses índices médios são profundamente afetados pelas redes públicas, que respondem por apenas um quarto das matrículas nos cursos de graduação presenciais. Nesse sentido, quando se desagregam os dados pelas redes de ensino (públicas e privada), pode-se inferir que uma proporção majoritária dos estudantes é atendida por docentes sem mestrado e, principalmente, sem doutorado.

Enquanto as redes públicas já superaram em 11 p.p. a meta de titulação mínima em nível de mestrado e em 23 p.p. a titulação mínima em nível de doutorado, a rede privada estava 6 p.p. aquém da primeira meta e 14 p.p. abaixo da segunda, conforme é mostrado no gráfico 31 . 
GRÁFICO 31

Percentual de docentes com titulação de mestrado e doutorado, segundo as redes de ensino - Brasil (2015)

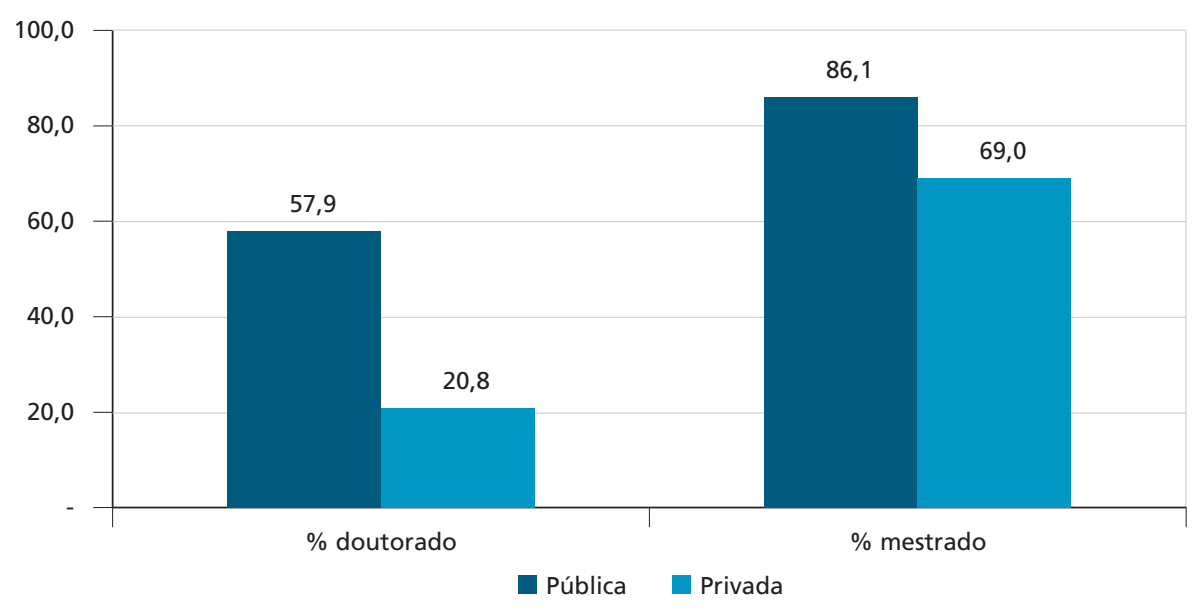

Fonte: Inep/MEC.

Elaboração: Disoc/lpea.

Tendo em vista que a rede privada respondia, em 2015 , por $72,5 \%$ das matrículas na modalidade presencial, a razão entre docentes titulados e estudantes matriculados é muito maior do que a existente nas redes públicas de ensino. Se nas IES privadas havia uma função docente com titulação mínima de mestrado para cada 31 matrículas, nas redes públicas a razão era de apenas 13 por 1 . Em relação aos docentes doutores, a desigualdade entre as redes de ensino é ainda maior. Entre as redes privadas, havia 104 matrículas por docente doutor, contra apenas 19 nas redes públicas. Portanto, a menor qualificação do corpo docente nas IES privadas contribui para aprofundar as diferenças de desempenho e formação entre seus estudantes e os das redes públicas.

Sob a ótica regional, verifica-se que as regióes Norte, Centro-Oeste e Nordeste encontram-se, nesta ordem, mais distantes de ambas as metas. Além disso, é maior a proporção de estudantes matriculados por docente titulado nessas regiōes. Por exemplo, na região Norte havia 219 estudantes matriculados por docente com titulação de doutor e 46 estudantes por docente com mestrado. A título de comparaçáo, no extremo oposto encontravam-se as redes públicas da região Sudeste, com 15 estudantes por docente doutor, e do Sul, com 11 estudantes por docente com titulação mínima de mestrado.

\subsubsection{Sobre a formação de mestres e doutores}

A formação de mestres e doutores foi definida como uma das metas do PNE 2014-2024. Desse modo, estabeleceu-se que, até o final desse decênio, deverão ser titulados anualmente 60 mil mestres e 25 mil doutores. 
Tendo em vista que, em 2015, foram titulados cerca de 55 mil mestres, o que corresponde a $91,5 \%$ da meta estabelecida para 2024, pode-se afirmar que é bastante factível atingi-la. Por sua vez, ainda que a meta relativa aos doutores se encontre mais distante dos 18,6 mil titulados em 2015, deve-se ter em conta que a taxa de incremento anual neste nível de formação tem sido maior que nos mestrados, o que favorecerá o atingimento da referida meta.

A pós-graduação stricto sensu é predominantemente ofertada pelas IES públicas (estaduais e federais), devido aos custos inerentes a este nível de ensino. No entanto, a rede privada teve aumento de sua participação no número de titulados em nível de doutorado, ao longo do período 2005-2015. Além disso, deve-se ressaltar que sua participação no total de titulados no mestrado profissional é bastante significativa, tal como pode ser observado na tabela 8 .

TABELA 8

Participação das redes de ensino no total de titulados da pós-graduação stricto sensu - Brasil (2005 e 2015)

\begin{tabular}{|c|c|c|c|c|c|c|c|c|}
\hline & \multicolumn{2}{|c|}{ Federal } & \multicolumn{2}{|c|}{ Estadual } & \multicolumn{2}{|c|}{ Municipal } & \multicolumn{2}{|c|}{ Privada } \\
\hline & 2005 & 2015 & 2005 & 2015 & 2005 & 2015 & 2005 & 2015 \\
\hline Mestrado & 52,7 & 56,6 & 25,8 & 25,6 & 0,7 & 0,6 & 20,9 & 17,2 \\
\hline Mestrado profissional & 31,7 & 45,0 & 15,0 & 9,0 & 3,5 & 1,0 & 49,8 & 45,0 \\
\hline Doutorado & 44,3 & 55,5 & 46,2 & 33,3 & - & 0,1 & 9,4 & 11,1 \\
\hline
\end{tabular}

Fonte: Capes/MEC.

Elaboração: Disoc/lpea.

Ao longo dessa década, inverteram-se algumas posiçōes entre as redes de ensino. De maneira geral, cresceu a participação da rede federal em todos os níveis, mas especialmente no mestrado profissional e no doutorado. No primeiro caso, havia preponderância do setor privado em 2005 e, no segundo, a liderança cabia às redes estaduais.

Essa alavancagem da rede federal se deveu aos investimentos realizados por intermédio do Programa de Apoio a Planos de Reestruturação e Expansão das Universidades Federais (Reuni). Além de o número de docentes ter sido duplicado no período 2005-2015, ampliou-se o contingente de doutores em cerca de $180 \%$. A título de comparação, o aumento do número de docentes com esta titulação nas IES estaduais foi de apenas a metade desse percentual.

Além do Reuni, também contribuiu para essa expansão a ampliação da concessão de bolsas de estudos pelo Conselho Nacional de Desenvolvimento Científico e Tecnológico (CNPq) e, principalmente, pela Coordenação de Aperfeiçoamento de Pessoal de Nível Superior (Capes). A participação das Ifes no total de bolsas concedidas por esta agência ampliou-se de 55,8\% para $63,4 \%$, no período em referência. 
Ressalte-se que, em nível de mestrado, houve um aumento na concessão de bolsas maior que o incremento das matrículas no período 2005-2015, conforme a tabela 9 .

TABELA 9

Matrículas e bolsas concedidas em cursos de mestrado e doutorado - Brasil (2005 e 2015)

\begin{tabular}{lrrrcc}
\hline & 2005 & 2015 & var. \% & Matrículas/bolsa & Matrículas/bolsa \\
\hline Mestrado & & & & & \\
Bolsas concedidas & 33.570 & 69.221 & 106,2 & & \\
Matrículas & 80.106 & 149.316 & 86,4 & 2,39 & 2,16 \\
Doutorado & & & & & \\
Bolsas concedidas & 27.177 & 60.988 & 124,4 & & 1,68 \\
Matríículas & 43.942 & 102.365 & 133,0 & 1,62 & \\
\hline
\end{tabular}

Fontes: Capes/MEC; CNPq/MCT.

Obs.: 1. Bolsas concedidas pela Capes e pelo CNPq.

2. Matrículas nas modalidades acadêmica e profissional.

Conforme é mostrado na tabela 9, houve redução do número de matrículas por bolsa concedida nos cursos de mestrado, enquanto em nível de doutorado ocorreu pequeno aumento. Porém, quando se comparam as taxas de crescimento das bolsas concedidas em cada nível de ensino, verifica-se que o maior aumento coube à modalidade de doutorado, condizente com a maior expansão das matrículas verificada neste caso.

\subsection{FINANCIAMENTO E GASTOS}

Após um período de contínua elevação do orçamento executado pelo MEC, o ano de 2015 marca a inflexão dessa trajetória ascendente, com queda de 13,3\%, ou R \$ 13,4 bilhōes, em valores constantes, em relação aos dispêndios realizados no ano anterior. Tal desempenho, como havia sido mencionado na apresentação deste capítulo, reflete a recessão econômica do país iniciada naquele ano.

As maiores quedas foram registradas na educação profissional e tecnológica (40\%) e na educação básica (35\%). Por sua vez, o orçamento executado na educação superior teve redução de cerca de $7 \%$. A queda menos acentuada na educação superior decorre da necessidade de a União manter sua rede de ensino, formada sobretudo pelas Ifes. Grosso modo, houve significativa diminuição nos investimentos em capital nos três níveis de ensino, mas as açóes voltadas ao apoio e à manutenção das redes federais de ensino também foram afetadas.

Uma das poucas açôes finalísticas de vulto que tiveram aumento de recursos foi a Concessão de Financiamento Estudantil, com 5,3\% de crescimento real. Quando se incluem os dispêndios com a administração desta ação, o orçamento executado 
amplia-se em cerca de 10\%. No entanto, esta ação está sob a alçada do Ministério da Fazenda e é de natureza reembolsável, pelo fato de conceder empréstimos aos estudantes da educação superior.

A tabela 10 contém a execução orçamentária do MEC no biênio 2014-2015, assim como do Fies, sob a alçada do Ministério da Fazenda. No caso do MEC, foram selecionadas as principais açóes finalísticas de cada programa, bem como aglutinadas dezessete açóes de investimentos em infraestrutura física das Ifes e dos hospitais universitários.

TABELA 10

Execução orçamentária do MEC e do Fies - Brasil (2014-2015)

\begin{tabular}{|c|c|c|c|}
\hline Ministério da Educação & 2014 & 2015 & var. \% \\
\hline Previdência de inativos e pensionistas da União & 11.538 .859 .060 & 11.652 .339 .285 & 1,0 \\
\hline Operações especiais: cumprimento de sentenças judiciais & 292.278 .209 & 263.777 .340 & $-9,8$ \\
\hline Operações especiais: serviço da dívida externa (juros e amortizações) & 76.305 & - & $-100,0$ \\
\hline Operações especiais: outros encargos especiais & 46.911 .258 & 2.257 .020 & $-95,2$ \\
\hline $\begin{array}{l}\text { Operações especiais: gestão da participação em organismos } \\
\text { internacionais }\end{array}$ & 55.973 .926 & 3.331 .959 & $-94,0$ \\
\hline Educação básica & 31.762 .093 .985 & 20.553 .245 .719 & $-35,3$ \\
\hline Concessão de bolsas de apoio à educação básica & 1.973.189.322 & 1.877.283.377 & $-4,9$ \\
\hline Dinheiro direto na escola para a educação básica & 2.781 .123 .860 & 1.476.191.219 & $-46,9$ \\
\hline Concessão de bolsa para equipes de alfabetização & 112.519 .115 & 66.565 .450 & $-40,8$ \\
\hline Apoio ao transporte escolar na educação básica & 633.659 .271 & 573.528 .618 & $-9,5$ \\
\hline $\begin{array}{l}\text { Complementação da União ao Fundo de Manutenção e Desenvolvimento } \\
\text { da Educação Básica e de Valorização dos Profissionais da Educação } \\
\text { - Fundeb }\end{array}$ & 11.840 .084 .093 & 10.614 .680 .616 & $-10,3$ \\
\hline Apoio ao transporte escolar para a educação básica - caminho da escola & 556.495 .946 & - & $-100,0$ \\
\hline Implantação de escolas para educação infantil & 2.923.271.993 & 10.116 .392 & $-99,7$ \\
\hline Implantação e adequação de estruturas esportivas escolares & 872.895 .382 & 15.962 .265 & $-98,2$ \\
\hline Funcionamento das instituições federais de educação básica & 107.575.219 & 91.548 .035 & $-14,9$ \\
\hline $\begin{array}{l}\text { Apoio à capacitação e formação inicial e continuada para a educação } \\
\text { básica }\end{array}$ & 407.670 .323 & 98.616 .379 & $-75,8$ \\
\hline Exames e avaliações da educação básica & 801.241 .338 & 501.538 .938 & $-37,4$ \\
\hline Infraestrutura para a educação básica & 1.869.259.475 & 187.195.101 & $-90,0$ \\
\hline $\begin{array}{l}\text { Produção, aquisição e distribuição de livros e materiais didáticos e peda- } \\
\text { gógicos para educação básica }\end{array}$ & 2.024.041.914 & 1.112.384.777 & $-45,0$ \\
\hline Elevação da escolaridade e qualificação profissional - ProJovem & 146.455 .085 & 31.890 .195 & $-78,2$ \\
\hline Apoio à Alimentação escolar na educação básica (Pnae) & 4.038.707.025 & 3.764 .635 .272 & $-6,8$ \\
\hline Apoio à alfabetização e à educação de jovens e adultos & 238.873 .579 & 10.809 .929 & $-95,5$ \\
\hline
\end{tabular}


(Continuação)

\begin{tabular}{|c|c|c|c|}
\hline Ministério da Educação & 2014 & 2015 & var. \% \\
\hline Educação profissional e tecnológica & 7.364.395.034 & 4.391 .957 .602 & $-40,4$ \\
\hline $\begin{array}{l}\text { Expansão e reestruturação de instituições federais de educação profissio- } \\
\text { nal e tecnológica }\end{array}$ & 738.997 .628 & 191.863 .628 & $-74,0$ \\
\hline $\begin{array}{l}\text { Funcionamento de instituições federais de educação profissionale } \\
\text { tecnológica }\end{array}$ & 2.148 .352 .974 & 1.394.906.748 & $-35,1$ \\
\hline Apoio à formação profissional, científica e tecnológica & 3.927 .031 .329 & 2.467 .064 .364 & $-37,2$ \\
\hline Assistência ao estudante da educação profissional e tecnológica & 359.667 .940 & 306.292 .443 & $-14,8$ \\
\hline $\begin{array}{l}\text { Modernização da rede pública não federal de educação profissional, } \\
\text { científica e tecnológica }\end{array}$ & 81.157 .434 & & $-100,0$ \\
\hline $\begin{array}{l}\text { Educação superior - graduação, pós-graduação, ensino, pesquisa e } \\
\text { extensão }\end{array}$ & 14.139 .522 .067 & 13.214.137.685 & $-6,5$ \\
\hline Apoio a entidades de ensino superior não federais & 35.110 .577 & - & $-100,0$ \\
\hline Apoio à residência em saúde & 482.127 .072 & 484.621 .722 & 0,5 \\
\hline Concessão de bolsas de estudos & 4.400 .153 .520 & 6.032 .523 .392 & 37,1 \\
\hline Concessão de bolsa-permanência no ensino superior & 84.499 .130 & 118.373 .100 & 40,1 \\
\hline $\begin{array}{l}\text { Fomento às ações de graduação, pós-graduação, ensino, pesquisa e } \\
\text { extensão }\end{array}$ & 493.200 .572 & 452.012 .174 & $-8,4$ \\
\hline Funcionamento de instituições federais de ensino superior & 4.003 .651 .624 & 3.040 .573 .742 & $-24,1$ \\
\hline Acesso à informação científica e tecnológica & 215.391.308 & 331.710 .256 & 54,0 \\
\hline Assistência ao estudante de ensino superior & 778.004 .000 & 713.169 .617 & $-8,3$ \\
\hline Funcionamento e gestão de instituições hospitalares federais & 256.408 .371 & 317.060 .203 & 23,7 \\
\hline $\begin{array}{l}\text { Ampliação, construção, implantação, modernização e reestruturação das } \\
\text { ifes e hospitais universitários (17 ações) }\end{array}$ & 3.228 .913 .452 & 1.645.183.955 & $-49,0$ \\
\hline Desenvolvimento produtivo & 2.834 .784 & - & $-100,0$ \\
\hline Programa de gestão e manutenção do Ministério da Educação & 35.748 .573 .335 & 37.455 .572 .668 & 4,8 \\
\hline $\begin{array}{l}\text { Contribuição da União, de suas autarquias e fundações para o custeio do } \\
\text { regime de previdência dos servidores públicos federais }\end{array}$ & 4.999 .761 .392 & 5.216.174.009 & 4,3 \\
\hline Auxílio-alimentação aos servidores civis, empregados e militares & 1.250 .815 .150 & 1.267 .388 .953 & 1,3 \\
\hline Pagamento de pessoal ativo da União & 27.341.467.952 & 29.470 .184 .285 & 7,8 \\
\hline Total & 100.951.517.962 & 87.536.619.278 & $-13,3$ \\
\hline Ministério da Fazenda (operações oficiais de crédito) & 2014 & 2015 & var. $\%$ \\
\hline Operações especiais: financiamentos com retorno & 13.228 .101 .625 & 13.933.373.913 & 5,3 \\
\hline Concessão de financiamento estudantil - Fies & 13.228 .101 .625 & 13.933.373.913 & 5,3 \\
\hline Administração do financiamento estudantil - Fies & 130.836 .180 & 776.755 .344 & 493,7 \\
\hline Total & 13.358.937.805 & 14.710.129.257 & 10,1 \\
\hline
\end{tabular}

Fonte: Siga Brasil.

Elaboração: Disoc/lpea.

Obs.: Em R\$ de dezembro de 2015. 
Conforme pode ser observado na tabela 10 , tanto a educação básica quanto a educação profissional e tecnológica tiveram redução dos dispêndios de todas as principais açóes finalísticas. Em relação à educação superior, em que pese o fato de terem caído à metade os investimentos em infraestrutura da rede federal, houve aumento dos gastos com a concessão de bolsas de estudos. Em valores absolutos, esse aumento foi equivalente à redução dos investimentos na ampliação e modernização das Ifes. No entanto, deve-se ter em conta que os dispêndios com o pagamento de pessoal ativo da União foram majorados em mais de R $\$ 2$ bilhóes, sendo que a maior parte deste montante coube às Ifes. Nesse sentido, pode-se afirmar que a educação superior foi o único nível de ensino que teve aumento de dispêndios no ano de 2015, mesmo tendo sido reduzidos em cerca de $24 \%$ os recursos destinados ao funcionamento das Ifes.

De modo geral, os investimentos em infraestrutura sofreram queda nos três níveis de ensino. Na educação básica, mediante repasses da União aos entes federados, a implantação de escolas de educação infantil e de quadras esportivas foi praticamente descontinuada. $\mathrm{Na}$ educação superior, caíram à metade os dispêndios com ampliação, construção e implantação de instituiçôes de ensino.

No entanto, a simples redução dos dispêndios de uma ação não significa necessariamente o corte de recursos e o comprometimento do atendimento aos estudantes. É o caso, por exemplo, do Programa Nacional do Livro Didático (PNDL), que é executado a partir de um calendário de distribuição de livros e materiais didáticos para a educação básica. Desse modo, em 2014 foram contemplados estudantes, professores e escolas dos anos finais do ensino fundamental, enquanto no ano seguinte foi a vez do ensino médio. Além disso, também é realizada de forma alternada a reposição integral dos chamados livros consumíveis (utilizados uma única vez), a reposição/complementação de livros reutilizáveis, bem como a distribuição de acervos para as bibliotecas escolares.

A título de comparação, havia 10,9 milhôes de matrículas nos anos finais do ensino fundamental, nas redes estaduais e municipais, em 2014. Por sua vez, o número de matriculados no ensino médio no ano seguinte, nessas mesmas redes de ensino, era de apenas 6,9 milhóes, ou seja, apenas 63\% daquele contingente, o que também implica menor quantidade de livros a serem adquiridos.

Por sua vez, o Fies, mesmo tendo sofrido corte brutal no número de contratos novos firmados em 2015, teve aumento de 5\% nos gastos realizados nesse ano. Isso se deve ao fato de o número de beneficiários concluintes ser menor que o de ingressantes no sistema.

Por fim, observa-se que a execução orçamentária de 2016, a ser analisada em detalhe na próxima edição deste periódico, mantém a tendência declinante iniciada no ano anterior. Tomando-se em conta a série histórica 2014-2016, verifica-se que houve redução de $17 \%$ nos gastos do MEC, entre o início e o final deste período, em valores atualizados para 2016, conforme é mostrado na tabela 11. 


\section{TABELA 11}

Execução orçamentária do MEC e do Fies - Brasil (2014-2016)

\begin{tabular}{lcccc}
\hline \multicolumn{1}{c}{ Modalidade de gasto } & 2014 & 2015 & 2016 & var. \% \\
\hline Gastos totais do MEC & 109.774 .227 .161 & 95.186 .926 .592 & 91.016 .516 .631 & $-17,1$ \\
Pagamento de pessoal ativo & 29.730 .989 .434 & 32.045 .746 .013 & 33.135 .205 .321 & 11,5 \\
Aposentadorias e pensões & 12.547 .303 .509 & 12.670 .701 .397 & 12.691 .070 .733 & 1,1 \\
\hline Complementação da União ao Fundeb & 12.874 .854 .257 & 11.542 .356 .021 & 11.712 .025 .848 & $-9,0$ \\
Apoio à alimentação escolar na educação básica (Pnae) & 4.391 .671 .877 & 4.093 .647 .484 & 3.427 .701 .246 & $-21,9$ \\
Dinheiro direto na escola para a educação básica & 3.024 .181 .593 & 1.605 .203 .701 & 1.315 .930 .927 & $-56,5$ \\
\hline Apoio à formação profissional, científica e tecnológica & 4.270 .236 .227 & 2.682 .674 .707 & 1.271 .104 .713 & $-70,2$ \\
Funcionamento de instituições federais de educação profissio- & 2.336 .109 .374 & 1.516 .815 .332 & 1.414 .423 .168 & $-39,5$ \\
nal e tecnológica & & & & $-26,0$ \\
\hline Concessão de bolsas de estudos no ensino superior & 4.784 .707 .172 & 6.559 .738 .839 & 3.541 .550 .347 & $-2,7$ \\
\hline Funcionamento de instituições federais de ensino superior & 4.353 .552 .792 & 3.306 .306 .229 & 4.237 .714 .216 & 22,0 \\
\hline Fies & 14.526 .448 .961 & 15.995 .728 .477 & 17.723 .993 .455 & 2 \\
\hline
\end{tabular}

Fonte: Siga Brasil.

Elaboração: Disoc/lpea.

Obs.: Em R\$ de dezembro de 2016.

Conforme pode ser observado na tabela 11, apenas os gastos relativos a pessoal (ativo e inativo) tiveram variação positiva no período 2014-2016. As maiores quedas foram registradas nas principais açóes que integram os três níveis de ensino.

\section{CONCLUSÃO}

O ano de 2015 foi marcado por forte inflexão na execução orçamentária do MEC, que, ao longo da última década, havia registrado crescimento contínuo dos dispêndios. Tendo em vista que se trata do primeiro exercício completo da vigência do PNE 2014-2024, uma vez que sua aprovação ocorreu em junho de 2014, tal inflexão gera incertezas quanto ao futuro deste plano decenal.

Considerando-se que esforços adicionais seriam necessários para o alcance das metas que o integram, tendo-se como referência a evolução ocorrida na década imediatamente anterior, torna-se ainda mais remota a probabilidade de tais metas serem atingidas, em virtude da redução em 2015 dos dispêndios da Uniáo destinados à manutenção e ao desenvolvimento da educaçáo básica.

O cenário também tende a se agravar sob a vigência da Emenda Constitucional (EC) $\mathrm{n}^{\circ} 95$, a partir de 2018 , tendo em vista que a ação supletiva da Uniáo a estados e municípios também será limitada pela referida EC, que estabeleceu que os dispêndios do governo federal não poderão ser ampliados nos próximos vinte anos, mas apenas corrigidos pelo índice inflacionário do período de doze meses encerrado em junho do ano anterior. Portanto, ficará inviabilizada a ampliação desses repasses na proporção que vinha ocorrendo até 2014. 
Considerando-se que o regime de colaboração entre os entes federados constitui peça-chave para a redução das desigualdades existentes e que a União tem exercido papel preponderante nesse sentido, ainda que insuficiente, pode-se afirmar que o Novo Regime Fiscal, instituído pela EC no 95, constitui outra limitação para o alcance das metas do PNE 2014-2024.

Se os desafios assumidos já se mostravam bastante ousados para serem superados no prazo de uma década, mas com a expectativa de ampliação dos investimentos públicos (meta 20), o cenário futuro se torna menos promissor, tendo em vista $\mathrm{o}$ aumento do desemprego e da vulnerabilidade social, associado aos cortes orçamentários. Portanto, muito deverá ser feito no campo da gestão para compensar tais carências e fragilidades, ainda que não se saiba em que medida tal compensação poderá ocorrer.

No intuito de reduzir a distância entre os resultados alcançados e as metas estabelecidas, esforços deverão ser empreendidos no equacionamento de uma problemática que tende a se agravar. De um lado, aumento das demandas sociais, potencializadas pela crise econômica; de outro, redução da capacidade de intervenção dos poderes públicos, em razão de deficit orçamentários, ou mesmo em função de decisóes de natureza política.

Desse modo, o primeiro ano efetivo da vigência do PNE 2014-2024 traz consigo certo ceticismo quanto ao atingimento de suas metas. Alguns dados corroboram tal entendimento. Segundo a Pnad 2015, houve redução na taxa de frequência à creche e, de acordo com o Censo Escolar, queda no número de matrículas na pré-escola. No outro extremo, também foi registrada diminuição do contingente de ingressantes nos cursos de graduação.

Dados do Censo Escolar 2016, divulgados recentemente, evidenciam forte redução das matrículas no ensino fundamental em período integral. Provavelmente, a principal causa dessa redução foi a paralisação do programa Mais Educação, a partir de 2015, que transferia recursos aos municípios para a ampliação da jornada escolar. Desse modo, esse retrocesso recente reforça a probabilidade de a meta 6 não ser atingida.

Em síntese, a combinação de fatores desfavoráveis, a partir de 2015, foi suficiente para produzir resultados que se apresentam como inflexôes na evolução de alguns indicadores educacionais ao longo da última década. Ante a perspectiva de retrocesso, redobram-se os desafios para viabilização dos objetivos e metas do PNE 2014-2024. 


\section{REFERÊNCIAS}

BRASIL. Portaria Normativa Interministerial no 17, de 24 de abril de 2007. Institui o Programa Mais Educação, que visa fomentar a educação integral de crianças, adolescentes e jovens, por meio do apoio a atividades socioeducativas no contraturno escolar. Brasília: Ministério da Educação, 2007.

. Decreto no 7.083, de 27 de janeiro de 2010. Dispóe sobre o Programa Mais Educação. Brasília: Congresso Nacional, 2010.

- Ministério da Educação. Instituto Nacional de Estudos e Pesquisas Educacionais Anísio Teixeira. Plano Nacional de Educaçáo PNE 2014-2024: Linha de Base. Brasília: Inep, 2015.

. Relatório do $1^{\circ}$ ciclo de monitoramento das metas

do PNE: biênio 2014-2016. Brasília: Inep, 2016. p. 117-122. Disponível em: $<$ https://goo.gl/Cj8tX2>.

OCDE - ORGANIZAÇÃO PARA A COOPERAÇÃO E DESENVOLVIMENTO ECONÔMICO. Brasil no PISA 2015: análises e reflexôes sobre o desempenho dos estudantes brasileiros /OCDE-Organização para a Cooperação e Desenvolvimento Econômico. - São Paulo: Fundação Santillana, 2016.

SOUSA; E. S. et al. Sistema de monitoramento e avaliaçáo dos programas Esporte e Lazer da Cidade e Segundo Tempo do Ministério do Esporte. Belo Horizonte: O Lutador, 2010. 184 p. 


\section{NOTAS METODOLÓGICAS}

Duas fontes principais, Ministério da Educação (MEC) e IBGE, foram utilizadas para compor os indicadores selecionados do Anexo Estatístico.

Para retratar a situação educacional da população, foram selecionados os seguintes indicadores: taxa de analfabetismo; média de anos de estudo; e proporção da populaçáo que frequenta escola. A cobertura e a oferta de serviços serão avaliadas por meio da proporçáo de docentes por grau de formação, e da matrícula de alunos por nível/modalidade de ensino. $\mathrm{O}$ último item concentra-se na produtividade/rendimento do sistema educacional. Com o objetivo de avaliar a situação educacional, utiliza-se a taxa de distorção idade/série do corpo discente e, na pós-graduação, a avaliação da Coordenação de Aperfeiçoamento de Pessoal de Nível Superior (Capes/MEC).

Os conceitos/definições utilizados nas tabelas construídas foram os mesmos das pesquisas originais, e são apresentados na sequência.

Anos de estudos (grau de instrução): a classificação segundo os anos de estudo foi obtida em razão da série e do grau que a pessoa estava frequentando ou havia frequentado, considerando a última série concluída com aprovação. A correspondência foi feita de modo que cada série concluída com aprovação estivesse relacionada a um ano de estudo. As pessoas que náo declararam a série e o grau, assim como as que apresentaram informaçôes incompletas ou que não permitissem a sua classificação, foram reunidas no grupo de anos de estudo "não determinados ou sem declaração".

Média de anos de estudos por faixa etária: fornece a média de séries concluídas com aprovação - por uma população de determinada faixa etária.

Alfabetização: considerou-se como alfabetizada a pessoa de 5 anos de idade ou mais, capaz de ler pelo menos um bilhete simples.

Taxa de analfabetismo por faixa etária: fornece a porcentagem de pessoas analfabetas em determinada faixa etária em relação ao total de pessoas do mesmo grupo etário. Para comparabilidade internacional, utiliza-se a faixa etária de 15 anos ou mais de idade.

Taxa de frequência à escola por faixa etária: indica a porcentagem da população por faixa etária que frequenta a escola, independentemente do grau de ensino em que está matriculado.

Taxa de frequência líquida por nivel/modalidade de ensino: identifica a parcela da populaçáo na faixa etária considerada adequada ao nível/modalidade de ensino a que se refere. As faixas etárias consideradas adequadas foram: educação infantil, menores de 6 anos; ensino fundamental, de 7 a 14 anos; ensino médio, de 15 a 17 anos; e ensino superior, de 18 a 24 anos. 
Docentes: refere-se às funções docentes, e não ao número de docentes (pessoa física). Se um professor leciona em mais de um estabelecimento escolar e/ou nível/modalidade de ensino, seráo contabilizadas tantas vezes quantas forem as funçóes que exerce.

Grau de formação: considera-se apenas o nível de formação mais alto concluído pelo docente. No caso de nível superior incompleto, considera-se como ensino médio completo, e no caso de ensino médio incompleto, considera-se como ensino fundamental completo.

Taxa de distorçâo idadelsérie: permite dimensionar e avaliar a distorção entre a idade dos alunos e a série que frequentam. Considera-se a idade recomendada para cada série/nível de ensino, ou seja, 7 anos para a $1^{\underline{a}}$ série do ensino fundamental, 8 anos para a $2^{\underline{a}}$ série, e assim sucessivamente. Se o aluno apresenta idade acima ( 2 anos ou mais) da recomendada para a série que frequenta, encontra-se em distorçâo em relação à série em que está matriculado, o que contribui para gerar distorção do fluxo escolar. Tal taxa é fornecida pelo quociente entre o número de alunos com distorção escolar em determinada série e o número de alunos matriculados nesta série.

Educação infantil: primeira etapa da educação básica, tem como finalidade o desenvolvimento integral da criança até 6 anos de idade, em seus aspectos físico, psicológico, intelectual e social, complementando a açáo da família e da comunidade. A educaçáo infantil pode ser oferecida em: $i$ ) creches ou equivalentes, para crianças de até 3 anos de idade; e ii) pré-escolas, para crianças de 4 a 6 anos de idade. Para efeito deste Anexo Estatístico, até 2003 incluía-se nesta etapa a classe de alfabetização. No entanto, a partir de 2004 o Instituto Nacional de Estudos e Pesquisas Educacionais Anísio Teixeira (INEP/MEC) deixou de coletar a matrícula inicial da classe de alfabetização, conforme determinado na meta no 15 do Plano Nacional de Educação, aprovado pela Lei no 10.172/2001: "Extinguir as classes de alfabetização incorporando imediatamente as crianças no ensino fundamental e matricular, também, naquele nível, todas as crianças de 7 anos ou mais que se encontrem na educação infantil”.

Classes de aceleração: classes especiais organizadas para o atendimento de alunos matriculados no ensino fundamental regular com atraso escolar (distorção idade-série de mais de 2 anos), o que possibilita a correção de sua trajetória escolar e sua reinserção no fluxo regular, bem como a consequente desobstrução e correção do fluxo escolar.

Ensino fundamental: considera-se como ensino fundamental (ensino regular) aquele oferecido em, pelo menos, 8 anos, com carga horária mínima anual de 800 horas, distribuídas por um mínimo de 200 dias de efetivo trabalho escolar Artigos 24 e 32 da Lei no 9.394, de 20 de dezembro de 1996 (Lei de Diretrizes e Bases da Educação Nacional - LDB). A partir da pesquisa do Censo Educacional de 2004, as séries iniciais do ensino fundamental abrangem as matrículas do $1^{\circ}$ ao $5^{\circ}$ ano e da $1^{\underline{a}}$ à $4^{\underline{a}}$ série, enquanto as séries finais compreendem as matrículas do 
$6^{0}$ ao $9^{\circ}$ ano e da 5a à $8^{\underline{a}}$ série. Tal procedimento se fez necessário para assegurar a comparabilidade dos dados da série histórica.

Ensino médio: etapa final da educação básica, com duração mínima de 3 anos, tem por finalidade consolidar e aprofundar os conhecimentos adquiridos no ensino fundamental.

Educação profissional: na LDB, esta modalidade de educação deve ser desenvolvida em articulação com o ensino regular ou por diferentes estratégias de educaçáo continuada, de modo a conduzir o aluno ao permanente desenvolvimento de aptidóes para a vida produtiva. Na regulamentaçâo dos Artigos 39 a 42 da mesma lei, o Decreto Federal no 2.208, de 17 de abril de 1997, configurou a educação profissional em três níveis de ensino: básico, técnico e tecnológico.

Os cursos de educação profissional técnica possuem organização curricular própria e se destinam a proporcionar habilitação profissional aos alunos matriculados ou egressos do nível médio.

Para melhor identificar os cursos de nível técnico, observe-se a Resolução no 4/1999, da Câmara de Educação Básica do Conselho Nacional de Educação (CEB/CNE), que institui as Diretrizes Curriculares Nacionais para Educação Profissional de Nível Técnico.

Os alunos matriculados na educação profissional de nível técnico formam um subconjunto dos alunos matriculados no ensino médio.

Educação especial: atendimento especializado a alunos portadores de necessidades especiais em escolas exclusivas para esta modalidade de ensino ou em classes especiais de escola regular.

Educação de jovens e adultos: atendimento, em cursos presenciais com avaliação no processo, de jovens e adultos que não tiveram acesso à escolarização regular na idade adequada.

Matrícula da pós-graduação: matrícula total existente ao fim do ano nos cursos de mestrado e doutorado nas redes pública e privada.

Conclusão da pós-graduação: número de alunos que concluíram mestrado ou doutorado durante o ano nas redes pública e privada por regiáo geográfica.

Avaliação da pós-graduação: a avaliação dos cursos de pós-graduação é realizada trienalmente pela Capes/MEC. Os conceitos utilizados na avaliação da Capes sofreram alteraçóes: até 1998, os cursos eram avaliados com conceitos entre A e E, sendo A o correspondente ao melhor conceito, e E, ao pior. A partir de 1998, alterou-se o sistema classificatório dos programas, o qual passou a ser realizado mediante escala numérica, de 1 a 7 , sendo este último o correspondente ao nível de maior qualidade. Além disso, passou-se a avaliar programas, e não cursos (mestrado e doutorado) separadamente. 
Outra inovação introduzida foi que os programas que ofertam apenas o nível de mestrado passam a ser avaliados em uma escala de 1 a 5 . A equivalência entre as escalas alfabética e numérica é a seguinte: $\mathrm{A}=5 ; \mathrm{B}=4 ; \mathrm{C}=3 ; \mathrm{D}=2 ; \mathrm{e} \mathrm{E}=1$.

Os programas que, em um primeiro momento, foram enquadrados no nível 5, submeteram-se a uma segunda etapa da avaliação, de modo que fossem identificados aqueles que apresentavam excelência e/ou padráo internacional. A estes casos atribuíram-se os conceitos 6 e 7. Para garantir a comparabilidade da série histórica, foram definidas apenas três categorias de conceitos: $\mathrm{A}=5$ a $7 ; \mathrm{B}=4$; e $\mathrm{C}=3$. Os conceitos $\mathrm{D}$ e $\mathrm{E}$ não foram considerados, pois não estão disponíveis informaçóes sobre os programas que tenham sido enquadrados nos níveis 1 e 2 . 


\section{TABELAS $^{9}$}

3.1 Média de anos de estudos de instrução formal, segundo categorias selecionadas Brasil e Grandes Regióes (1992-2015)

3.2 Taxa de analfabetismo, segundo categorias selecionadas - Brasil e Grandes Regiōes (1992-2015)

3.3 Proporção de crianças e jovens que frequentam escola, segundo categorias selecionadas - Brasil e Grandes Regióes (1992-2015)

3.4 Taxa de frequência líquida à escola, segundo nível/modalidade de ensino e categorias selecionadas - Brasil e Grandes Regióes (1992-2015)

3.5 Proporção de pessoas com diploma de ensino fundamental, na faixa etária de 15 a 18 anos - Brasil e Grandes Regióes (1992-2015)

3.6 Proporção de pessoas com diploma de ensino médio, na faixa etária de 18 a 24 anos - Brasil e Grandes Regióes (1992-2015)

3.7 Proporção de pessoas com diploma de curso superior, segundo faixas etárias Brasil e Grandes Regióes (1992-2015)

3.8 Indicadores do ensino de graduação, segundo a natureza administrativa - Brasil e Grandes Regióes (1990-2013)

3.9 Matrícula na pós-graduação stricto-sensu, por tipo de curso e redes pública e privada - Brasil e Grandes Regióes (1996-2014)

3.10 Diplomados da pós-graduação nas redes pública e privada, segundo tipo de curso - Brasil e Grandes Regióes (1996-2014)

3.11 Distribuição percentual dos conceitos obtidos pelos cursos de pós-graduação na avaliação da Capes, segundo rede de ensino - Brasil e Grandes Regióes (1992, 1998, 2001, 2004, 2007, 2010 e 2013) 
Ipea - Instituto de Pesquisa Econômica Aplicada

\section{Assessoria de Imprensa e Comunicação}

\section{EDITORIAL}

\section{Coordenação}

Cláudio Passos de Oliveira

\section{Supervisão}

Everson da Silva Moura

Leonardo Moreira Vallejo

\section{Revisão}

Ana Clara Escórcio Xavier Camilla de Miranda Mariath Gomes

Clícia Silveira Rodrigues

Idalina Barbara de Castro

Olavo Mesquita de Carvalho

Regina Marta de Aguiar

Reginaldo da Silva Domingos

Alice Souza Lopes (estagiária)

Hislla Suellen Moreira Ramalho (estagiária)

Isabela Monteiro de Oliveira (estagiária)

Lilian de Lima Gonçalves (estagiária)

Lynda Luanne Almeida Duarte (estagiária)

Luiz Gustavo Campos de Araújo Souza (estagiário)

Polyanne Alves do Santos (estagiária)

\section{Editoração}

Aeromilson Trajano de Mesquita

Bernar José Vieira

Cristiano Ferreira de Araújo

Danilo Leite de Macedo Tavares

Herllyson da Silva Souza

Jeovah Herculano Szervinsk Junior

Leonardo Hideki Higa

\section{Capa}

Danielle de Oliveira Ayres

Flaviane Dias de Sant'ana

The manuscripts in languages other than Portuguese published herein have not been proofread.

\section{Livraria Ipea}

SBS - Quadra 1 - Bloco J - Ed. BNDES, Térreo

70076-900 - Brasília - DF

Tel.: (61) 2026-5336

Correio eletrônico: livraria@ipea.gov.br 

Composto em adobe garamond pro 11/13,2 (texto) Frutiger 67 bold condensed (títulos, gráficos e tabelas) Brasília-DF 



\section{Missão do Ipea}

Aprimorar as políticas públicas essenciais ao desenvolvimento brasileiro por meio da produção e disseminação de conhecimentos e da assessoria ao Estado nas suas decisões estratégicas. 